\title{
Seasonal phytoplankton dynamics in the coastal waters of the north-eastern Adriatic Sea
}

Jelena Godrijan $^{\mathrm{a} *}$, Daniela Marić ${ }^{\mathrm{a}}$, Igor Tomažić ${ }^{\mathrm{b}}$, Robert Precali ${ }^{\mathrm{a}}$ and Martin Pfannkuchen ${ }^{\mathrm{a}}$

${ }^{a}$ Center for Marine Research, Ruđer Bošković Institute, Giordano Paliaga 5, 52210 Rovinj, Croatia.

${ }^{\mathrm{b}}$ Division for marine and environmental research, Ruđer Bošković Institute, Bijenička cesta 54, 10000 Zagreb, Croatia.

*Corresponding author: E-mail: jelena.godrijan@irb.hr

Tel: $+385-52-084-763 \quad$ Fax: $+385-52-813-496$ 


\begin{abstract}
This study describes the dynamics of phytoplankton in relation to environmental factors in coastal waters of the north-eastern Adriatic Sea. The distant Po River's influence is rarely noted on the eastern coastal part of the northern Adriatic, but it does trigger the crucial alternations in the community, e.g. mass development of diatoms in July 2009. A highly variable ecosystem, like the northern Adriatic, sustains high species diversity. Even though quite a few species were present for more than several months, we identified the seminal species of the seasonal succession. During spring Prorocentrum micans, Leptocylindrus minimus, Chaetoceros throndsenii, Ceratium furca and $C$. fusus were most characteristic. These species thrive in low salinity and mixed waters. Typical summer diatom species were Chaetoceros vixvisibilis, Proboscia alata, while Rhabdosphaera clavigera and Syracosphaera pulchra were identified as distinctive summer coccolithophorids. All the summer species preferred warmer waters with low nitrate and low silica content. The autumn community was characterised by species such as Calciosolenia murrayi, Chaetoceros socialis, Asterionellopsis glacialis, Lioloma pacificum. These species related to high nutrient conditions, but also to low Po River influence. In winter a prevalence of large diatoms Thalassiosira rotula, Neocalyptrella robusta and Pseudosolenia calcar-avis was recorded. The winter assemblage was characterised by species of cold water preference able to grow in well mixed conditions.
\end{abstract}

Keywords: coastal ecosystem; northern Adriatic Sea; phytoplankton succession; seasonal dynamics 


\section{Introduction}

The Mediterranean is a semi-enclosed sea usually thought of as an oligotrophic system (Sournia, 1973), with the exception of several small coastal areas where higher production is primarily influenced by large rivers (Gómez and Gorsky, 2003). One such system is the northern Adriatic Sea, a shallow basin $(<50 \mathrm{~m})$ with marked west to east gradients of physical and biological properties. Discharges of the Po River and different circulation patterns were identified as major drivers of nutrient input and distribution (Cozzi and Giani, 2011; Degobbis et al., 2000), and thus phytoplankton community composition in the whole area (Viličić et al., 2009). The Po River exhibits two principal patterns of its influence on the northern Adriatic ecosystem. In mixed conditions the Po River water is confined to the western coast, it flows into the Western Adriatic Current (WAC) and eventually exits the Adriatic (Cushman-Roisin et al., 2001; Mauri and Poulain, 2001). Otherwise, it can extend into the northern Adriatic interior. There it forms the Po River plume, either as a tongue of fresh water or it spreads as a thin surface layer over the entire northern Adriatic basin during stable, stratified conditions (Bignami et al., 2007; Cushman-Roisin et al., 2001). Additionally, the eastern part of the northern Adriatic Sea is under influence of highly saline, oligotrophic waters by advection of the Eastern Adriatic Current (EAC) from the central Adriatic. Satellite surface chlorophyll $a$ maps proved to be important tools in studying the spatial structure and temporal variation of the Po River plume. Surface chlorophyll $a$ is considered to be a marker of the spatial productivity patterns in the northern Adriatic ecosystem and the basin's mesoscale dynamics (Mauri and Poulain, 2001).

Detailed knowledge of phytoplankton dynamics is essential for our understanding of the marine ecosystem, particularly in marginal seas, like the northern Adriatic, where responses to external changes are amplified. Generally, the annual pattern of phytoplankton biomass in temperate systems is thought to have two major maxima, in spring and autumn (Legendre, 1990). For the northern Adriatic, though, four major peeks were reported by Bernardi Aubry et al. (2012) (February, May, July and September). These blooms are dominated by diatoms (Marić et al., 2012), with the exception of May when nanoflagellates co-dominate (Bernardi Aubry et al., 2012; Mozetič et al., 2012). Dinoflagellates reach their peak in the summer in offshore waters (Totti et al., 2000), but are rarely more abundant than diatoms in the coastal area of the Gulf of Venice (Bernardi Aubry and Acri, 2004). Revelante and Gilmartin (1976) reported a less pronounced spring bloom (chlorophyll $a$ and biomass) in the eastern part of the northern Adriatic if compared to the western part of the northern Adriatic basin. In the last decade a reduction of diatoms was reported in the eastern part of 
the northern Adriatic, while the development of the spring peak shifted towards summer (Marić et al., 2012; Mozetič et al., 2012). However, scarce information is available on species succession and phytoplankton dynamics of the eastern part of the northern Adriatic.

In this report we investigate the phytoplankton community and species dynamics in coastal waters of the less investigated eastern part of the northern Adriatic Sea. Observation of species composition provides insight into mechanisms and trophic implications not resolvable with measurements of chlorophyll $a$ or other bulk parameters alone (Ji et al., 2010). Moreover, as spatial heterogeneity of the phytoplankton composition can strongly influence the ecosystem stability, dynamics and regional productivity (Martin, 2003), a comprehensive information on this is clearly vital to an understanding of the northern Adriatic ecosystem. This two year study (2008-2009) integrates timing, abundance and spatial distribution of phytoplankton. We compare satellite chlorophyll distributions with in situ measurements of both chlorophyll $a$ concentrations and phytoplankton species abundances. We aim not just to detail the spatial distribution and influence of the distant Po River on the phytoplankton community but also to reveal the temporal succession of species in coastal waters of the north-eastern Adriatic.

\section{Materials and methods}

\subsection{Sampling}

Eighteen monthly cruises, from March 2008 until November 2009, were carried out with the RV 'Vila Velebita'. Gaps in sampling were due to maintenance of the ship. Samples were collected at seven stations, all one nautical mile from the Croatian coastline (Fig 1). The stations formed a transect along the Istrian coast. Conductivity-Temperature-Depth (CTD) profiles were recorded with an SBE 25 Sealogger CTD probe (Sea-Bird Electronics, Inc., Bellevue, Washington, USA). Water samples were collected with $5 \mathrm{~L}$ Niskin bottles at surface, 5, 10, $20 \mathrm{~m}$ and $2 \mathrm{~m}$ above seabed for nutrients; and at surface, $10 \mathrm{~m}$ and $2 \mathrm{~m}$ above seabed for phytoplankton analyses.

\subsection{Sample analysis}

Nutrients: nitrate $\left(\mathrm{NO}_{3}\right)$, nitrite $\left(\mathrm{NO}_{2}\right)$, orthophosphate $\left(\mathrm{PO}_{4}\right)$ and orthosilicate $\left(\mathrm{SiO}_{4}\right)$ were measured by spectrophotometric methods (Parsons et al., 1984). Ammonium $\left(\mathrm{NH}_{4}\right)$ was analysed by a modified technique of the indophenol method (Ivančić and Degobbis, 1984). Measurements were performed on a Shimadzu UV-Mini 1240 spectrophotometer with $10 \mathrm{~cm}$ cells. In statistical analyses total inorganic nitrogen (TIN, sum of $\mathrm{NO}_{3}, \mathrm{NO}_{2}$, and $\mathrm{NH}_{4}$ ) was used. 
A $500 \mathrm{ml}$ subsample for the determination of chlorophyll $a$ was filtered onto Whatman GF/C filters and immediately frozen at $-20^{\circ} \mathrm{C}$ until analysis (within a week). Total chlorophyll $a$ concentrations were determined on a Turner TD-700 fluorometer (Parsons et al., 1984) after three hours extraction in $90 \%$ acetone (in the dark, with grinding). Satellite data of the MODIS/Aqua chlorophyll concentration, derived with the OC3 algorithm (O' Reilly et al., 2000) were retrieved from the Ocean Colour Web archive (Feldman and McClain, 2009). Series of satellite images were attained to observe the conditions in the rest of the basin.

Phytoplankton samples, $200 \mathrm{ml}$, were fixed with neutralised formaldehyde ( $2 \%$ final concentration). Phytoplankton cells were counted in $50 \mathrm{ml}$ subsamples after 40 hour of sedimentation time (Hasle, 1978) using an Axiovert 200 microscope (Zeiss GmbH, Oberkochen, Germany) and following the Utermöhl (1958) method. Microplankton and nanoplankton were differentiated according to cell dimensions (Sieburth et al., 1978). Identified taxa were grouped to diatoms, dinoflagellates, silicoflagellates, coccolithophores and flagellates (which included: chlorophytes, chrysophytes, cryptophytes and prasinophytes) according to (Tomas, 1997). Cells that could not be identified to the species level were classified to genus level (e.g. diatom groups such as Cyclotella, Pleurosigma and Navicula or dinoflagellates as Gyrodinium), or a species complex (e.g. Pseudo-nitzschia). In statistical analyses only species data was considered.

\subsection{The Po River flow}

Daily discharge rates of the Po River were measured at Pontelagoscuro (445' $\mathrm{N}, 11^{\circ} 36^{\prime} \mathrm{E}$ ), Italy, the last station before the river deltic ramification and $70 \mathrm{~km}$ from the sea coast. The data were supplied by Assessorato Programmazione, Pianificazione e Ambiente of the Emilia Romagna region (Italy).

\subsection{Data analyses}

Cluster analysis was applied to delineate possible grouping of stations. The analysis was based on Bray-Curtis coefficients computed from $\log (\mathrm{x}+1)$ transformed phytoplankton species abundances (Clarke et al., 2006). Species principally contributing to differences in community structure in each season were investigated using the similarities percentage procedure, SIMPER (Clarke and Warwick, 2001). Seasons were defined as follows: spring (March-May), summer (June-August), autumn (September-November) and winter (December-February); corresponding to summer stratified and winter mixed water column conditions and two transient seasons (spring and autumn). Canonical correspondence analysis (CCA; CANOCO version 4.5) (Braak and Šmilauer, 2002), a multivariate method based on linear regressions, was used to investigate relationships between 
species composition and environmental factors. Species were selected on the basis of SIMPER analysis, and both species abundances and environmental data were $\log (\mathrm{x}+1)$ transformed to obtain normal distribution. Furthermore, a nonparametric statistical analysis, Spearman rank correlation, was made between environmental variables and selected species to further confirm their relations.

All statistical analysis were performed with Systat (Systat Software, Inc., Chicago, USA), Statistica (StatSoft Inc.,Tulsa, USA), Primer (PIMER-E Ltd, Plymouth, UK), Matlab (Mathworks, Massachusetts, USA), and Canoco (Biometris, Wageningen, The Netherlands) software. Graphical representations of data were done with Grapher and Surfer software (Golden software, Inc., Golden, USA).

\section{Results}

\subsection{Environmental conditions}

A complete vertical mixing during winter occurred, as seen in temperature, salinity and density distributions (Fig 2A-C). Temperature and density vertical gradients occurred in spring and became stronger in summer. The waters affected by the Po River plume, as shown by lower salinity, were observed during the stratification period and most clearly recognizable in July 2009 when they spread throughout the surface layer over the whole basin. The water column started to destabilise in autumn, in 2008 already in September, while in 2009 it started in October. During the study period TIN and $\mathrm{SiO}_{4}$ were always an order of magnitude higher than $\mathrm{PO}_{4}$ (Fig 2D-E). Concentrations of $\mathrm{PO}_{4}$ ranged from the detection limit until $0.18 \mu \mathrm{mol} \mathrm{L}{ }^{-1}$, TIN concentrations ranged 0.17-6.32 $\mu \mathrm{mol}$ $\mathrm{L}^{-1}$ while $\mathrm{SiO}_{4}$ between $0.01-12.28 \mu \mathrm{mol} \mathrm{L}^{-1}$. All nutrients were generally higher in the autumn/winter period.

The annual cycle of surface chlorophyll $a$ concentrations measured in water samples coincided to a certain extent with satellite chlorophyll measurements (Fig 3, supplementary Fig 1). The highest surface chlorophyll $a$ was recorded in autumn (Fig 3), with a maximum in November 2009 (1.47 $\mu \mathrm{g}$

$\mathrm{L}^{-1}$ ). In the bottom layer values up to $5.2 \mu \mathrm{g} \mathrm{L}^{-1}$ and $3.7 \mu \mathrm{g} \mathrm{L}^{-1}$ were measured in July 2008 and October 2009, respectively. The Po River flow was on average $1840 \mathrm{~m}^{3} \mathrm{~s}^{-1}$ (SD $1294 \mathrm{~m}^{3} \mathrm{~s}^{-1}$ ) through the investigated period. The highest flow was recorded in May $2009\left(8073 \mathrm{~m}^{3} \mathrm{~s}^{-1}\right)$, while the lowest in April $2008\left(518 \mathrm{~m}^{3} \mathrm{~s}^{-1}\right)$.

\subsection{Phytoplankton community}

In the study 202 phytoplankton taxa were observed, 153 identified to a species level. Diatoms were the richest group with 107 taxa, followed by dinoflagellates with 78 taxa. The genus Chaetoceros 
(27 species) was the most diverse among diatoms and the genus Ceratium (18 species) among dinoflagellates (Table 1, supplementary Table 1).

During the investigated period abundances ranged from $21 \cdot 10^{3}$ cells $1^{-1}$ (September $2009,30 \mathrm{~m}$ JPG35) to $2893 \cdot 10^{3}$ cells $^{-1}$ (July 2009, 10 m JPG37) (Fig 4). The highest abundances were observed in autumn/winter (October 2008-January 2009) and July 2009, while the lowest abundances were observed in spring and late summer (March 2009 and August-October 2009, respectively). During spring the community was dominated by nanoplankton with more than $70 \%$ of the total cell counts (Fig 4), namely coccolithophorids and cryptophytes. Dinoflagellates contributed to the community with maximum 20\% in March 2009. Diatoms were found to be contributing to the community with more than $50 \%$ in the summer period, while dinoflagellates contributed to the summer community with around $10 \%$ (species of the genera Ceratium, Dinophysis and Prorocentrum; Table 1, supplementary Table 1). Diatoms were contributing with more than 50\% during autumn (species of the genera Chaetoceros and Pseudo-nitzschia; Table 1, supplementary Table 1). In 2008 this happened already in September, while in 2009 the autumn bloom shifted towards November (Fig 4). The winter period was dominated by coccolithophorids and diatoms.

\subsection{Spatial variability along the investigated transect}

Satellite chlorophyll $a$ images revealed almost constantly high chlorophyll $a$ concentrations in the western area of the northern Adriatic, while the eastern area only rarely developed such high chlorophyll $a$ values in surface waters (supplementary Fig 2). Along the eastern coast of the northern Adriatic (studied area) satellite chlorophyll $a$ images showed a north to south gradient of chlorophyll $a$ with generally higher values to the north (supplementary Fig 2). This correlated well with our cell counts for this area, where we noted higher values at the northern stations (JPI01JPG37) if compared to the values from the more southern stations (JPG33-36) (Figs 5-6).

Cluster analysis of the species and abundance data grouped the stations along the north-eastern Adriatic coast in accordance with the satellite chlorophyll $a$ data (Fig 7, supplementary Fig. 2). However, northern and southern stations were only markedly separated during spring (Fig 7A). In other seasons differences among stations were less evident by the cluster analysis. It was apparent, though, that the grouping of stations was influenced by the Po River under stratified conditions. On the satellite chlorophyll images distinctive Po River plumes reaching the Istrian coast were observed in September 2008, July 2009 and September 2009, when surface abundances were higher at the influenced stations (JPG38, all stations and JPG36, respectively). Stations were grouped according to the shape and direction of the plume. In the case when the plume covered the whole 
basin (July 2009) all stations were grouped together (Fig 7B). During the mixing period, phytoplankton was evenly distributed throughout the water column, while during the stratified periods higher abundances were recorded for the upper water layers (Figs 5-6).

\subsection{Seasonal dynamics of species}

To reveal the seasonal pattern of phytoplankton in the coastal waters of Istria 34 dominant species were selected on the basis of simper analysis (Table 2). Several species were found to persist over all seasons: Emiliania huxleyi, Cerataulina pelagica, Thalassionema nitzschioides, Guinardia flaccida, Rhizosolenia imbricata, Guinardia striata and Dactyliosolen fragilissimus. We also found species characteristic for each season. During spring most characteristic were Prorocentrum micans, Leptocylindrus minimus, Chaetoceros throndsenii, Ceratium furca and C. fusus. Typical summer diatom species were Chaetoceros vixvisibilis, Proboscia alata, while Rhabdosphaera clavigera and Syracosphaera pulchra were identified as distinctive summer coccolithophorids. The autumn community was characterised by species such as Calciosolenia murrayi, Chaetoceros socialis, Asterionellopsis glacialis, Lioloma pacificum. In winter a prevalence of large diatoms Thalassiosira rotula, Neocalyptrella robusta and Pseudosolenia calcar-avis was recorded.

\subsection{Linking environment and species.}

A Canonical Correspondence Analysis (CCA) was used to relate species to the environmental variables. The first two ordination axes from the CCA explained $61 \%$ of the total spatial distribution of phytoplankton groups. The first axis had an eigenvalue of 0.17 and explained $33 \%$, while the second had an eigenvalue of 0.14 and explained $28 \%$. The ordination revealed five relatively distinct groups of phytoplankton species (Fig 8).

Species characterizing the spring season, P. micans and C. furca, related positively to temperature, and negatively to salinity and density (Table 3). They were grouped with L. minimus and other Ceratium species (Fig 8). Typical summer diatom species $C$. vixvisibilis, P. alata f. gracilima, $R$ clavigera and S. pulchra, were positively correlated with temperature, negatively with TIN and $\mathrm{SiO}_{4}$ (Table 3). They were grouped with Hemiaulus haucki and Dactyliosolen fragilissimus (Fig 8). An autumn group with $C$. murrayi, A. glacialis, L. pacificum and C. socialis significantly positively correlated with $\mathrm{PO}_{4}$, TIN, and negatively with Po flow (Table 3). Similar correlations were found with Ophiaster hydroideus, Paralia sulcata and Dictyocha fibula (Fig 8). The winter species Thalassiosira rotula, Neocalyptrella robusta were negatively related to temperature and positively with TIN and density (Table 3). Similar relations were found with Chaetoceros danicus, Chaetoceros throndsenii and Skeletonema marinoi, although not all significant. Pseudosolenia 
calcar-avis did not relate to any investigated parameter. As for the species present over all seasons, Cerataulina pelagica and Rhizosolenia imbricata appeared to group with the spring assemblage and Dactyliosolen fragilissimus with summer species (Fig 8).

\section{Discussion}

\subsection{Phytoplankton community structure}

During this two year study a high number of phytoplankton taxa were observed, with a prevalence of diatom species. In the study done by Viličić et al. (2009), in the north-eastern Adriatic Sea during the 2002-2007 period, a comparable numbers of taxa was noted. The community's main composites were: Chaetoceros, Pseudo-nitzschia, Proboscia, Rhizosolenia, Pseudosolenia, Cerataulina, Leptocylindrus and Thalassionema, all of which were found to be important in the phytoplankton community in this study as well. Contrary to this, Gomez and Gorsky (2003) found that the Ligurian Sea (northern Mediterranean) phytoplankton community was mainly composed of dinoflagellate species. Total phytoplankton abundances during our study were one order of magnitude lower than recorded at inlets of the Lagoon of Venice (Bernardi Aubry and Acri, 2004). However, compared with results from the middle and northern Adriatic Sea (Totti et al., 2000; Viličić et al., 2009) they were of similar scale.

Revelante and Gilmartin (1976) found nanoplankton to continuously dominate the phytoplankton community of the north-eastern Adriatic, with contributions averaging from $74 \%$ to $88 \%$. Here we found an alternation in dominance between the nano and micro fraction of phytoplankton. We recorded a spring prevalence of nanoplankton, also reported by Mozetič et al. (2012) and Viličić et al. (2009). They found cryptophytes to be dominating during this period. Mozetič et al. (2012) proposed that the absence of a top-down control allowed nanoplankton to burst out in spring. This was concurrent with the declining microzooplankon, their main predator. Monti et al. (2012) observed a shift from two seasonal peaks in April and August to only one seasonal peak in September. During summer, diatoms were dominating especially during the July 2009 event which coincided with a spread of the Po River plume toward the Istrian coast (Fig 7, supplementary Fig 1.), indicated also by a salinity drop and high TIN concentration. These elevated summer peaks have been reported from 2000 onwards for the eastern part of the northern Adriatic (Marić et al., 2012; Mozetič et al., 2012).

A strong deficiency of orthophosphate versus inorganic nitrogen supply from the Po River is a condition regularly observed for the region (Cozzi and Giani, 2011). Phytoplankton overcomes this condition via utilization of dissolved organic phosphorus by alkaline phosphatase activity in 
summer (Ivančić et al., 2009). In addition, Frka et al. (2011) report the enhanced synthesis of monogalactosyldiacylglycerols during summer. These non phosphorus membrane lipids could help sustain the increase in biomass during phosphate limited conditions. The predominance of diatoms during bloom periods, even during the summer stratification like we recorded, was also noted in research by Varela et al. (2008). During this period dinoflagellate assemblages were made up by a rich assemblage of species of Ceratium, Dinophysis and Prorocentrum. Similar results are reported for the western coast of the northern Adriatic (Bernardi Aubry et al., 2004). The autumn bloom in the northern Adriatic is attributed to diatoms and coincides with the breakdown of stratification that allows the upward flux of nutrients from the bottom. The bloom in 2008 started sooner than one in 2009 , due to a later onset of mixing in 2009. A high diversity of species of the genus Chaetoceros was recorded. A similar dominance of the genus Chaetoceros in the autumn period was reported by Pannard et al. (2008) and related to increased light availability and high silicon stock. Like previously reported, we found Pseudo-nitzschia to be the most abundant (potentially) toxic species in autumn in the northern Adriatic (Marić et al., 2011). We found that winter phytoplankton maximum could be attributed to coccolithophorids. Similar coccolithophorid dominated winter maximum was reported for parts of the western Adriatic coast and the middle Adriatic (Bernardi Aubry et al., 2004; Viličić et al., 2009).

\subsection{Spatial aspect of the phytoplankton community and the Po River influence}

The Po River causes pronounced spatial variability of phytoplankton abundance and biomass in the Adriatic Sea, especially in the western coastal waters (Bernardi Aubry et al., 2006; Mangoni et al., 2008). Eastern coastal waters are less influenced by the Po River and more spatially homogenous. The eastern coastal zone rarely exhibits high chlorophyll $a$ concentrations and can be characterized as a separate system if compared to the western coastal waters. This west to east difference was also reflected in phytoplankton composition as diatom-dominated and phytopflagellate-dominated areas, respectively, and separated by a front (Mangoni et al., 2008). Mangoni argued that phytoplankton assemblages compensate for nutrient depletion and hydrographical constraints, by means of size and taxonomic composition.

Viličić et al. (2009) discussed in detail spatial the distribution of phytoplankton assemblages of the north-eastern Adriatic Sea. They conclude that the phytoplankton in the eastern coastal area is greatly influenced by oligotrophic karstic rivers. The north-eastern Adriatic rivers discharge about $12 \%$ of the total nitrogen input and $5 \%$ of the total phosphorus input into the northern Adriatic Sea (Cozzi and Giani, 2011). The here reported increase of phytoplankton abundance from south towards north seems to support this conclusion. Nevertheless, the grouping of the here investigated 
stations was also related to diluted influences of the Po River. Separation of our most southern station (JPG33) by multivariate analysis of phytoplankton agreed with the isolation of the southern station Zi209 in a study by Viličić et al. (2009). This was explained by its position in the transition area, where the influence of the EAC and of less saline northern Adriatic waters frequently change (Viličić et al., 2009). Moreover, grouping of the most southern stations in the spring period coincided with the period of the strongest EAC inflow from the south (Poulain and Raicich, 2001). This inflow of oligothropic EAC waters might be related to the dominance of nanoplankton in the whole area during this period.

Throughout the rest of the years no clear pattern in grouping of the stations was observed. This indicates that the eastern coastal waters of the northern Adriatic are one connected area. Extent and direction of the Po River plume sporadically influenced the grouping of the stations, mainly under stratified conditions, e.g. July and September. This indicates a combined effect of both climate and human (via river nutrient inputs) influence on the magnitude of phytoplankton blooms in the Istrian coastal waters. This kind of synergetic effect was explained by Breton et al. (2006) by relating the dominance of Phaeocystis colonies over diatoms to the North Atlantic Oscillation and freshwater and continental nitrate carried by the Scheldt River. According to Cushman-Roisin et al. (2001) the water circulation in the northern Adriatic Sea is under the influence of local wind dominance and rainfall, both being climate driven. Climate, thus, influences the extent of spreading nutrient inputs from the Po River towards the Istrian coastal waters, and in the end the size of phytoplankton blooms.

\subsection{Seasonal succession of the phytoplankton species}

Some of the ubiquitous species, namely: Dactyliosolen fragilissimus, Cerataulina pelagica and Guinardia striata are common bloom-forming taxa (Gómez and Gorsky, 2003), and it is presumed that these diatoms benefit from the ability to store nutrients and prosper in environments where nutrients are available in pulses (Phlips et al., 2010). Further, highest concentrations of another ubiquitous species, Thalassionema nitzschioides, were observed in July 2009. This was found to positively correlate with all the nutrients. Sudden availability of nutrients hence propagated the proliferation of this species. Bode et al. (2005) found the diatom T. nitzschioides to dominate the community during upwelling pulses. Emiliania huxleyi was the most frequent species recorded in our study, with highest abundances during winter. E. huxleyi was related to low temperature and nutrient rich waters, as also reported by Haidar and Thierstein (2001). Bernardi Aubry et al. (2006) found E. huxleyi to be typical for the mixing period and summer deep waters in the northern 
Adriatic Sea. This coccolithophorid is ubiquitous in both coastal and oceanic waters and regularly forms extensive blooms, particularly at mid-latitudes (Head et al., 1998).

Prorocentrum micans, one of the species characterising spring assemblages, is usually found over wide ranges of water temperatures, salinities and nutrient concentrations (Alkawri and Ramaiah, 2010). In our study it responded well to the temperature increase in spring. Dinoflagellates of the genus Ceratium were found rather frequently, albeit in low abundances. In the spring period they reached highest abundances. Ceratium furca preferred lower salinity waters which are usually of higher nutrient concentrations, similar to findings of Alkawri and Ramaiah (2010). The spring diatom Leptocylindrus minimus in our study significantly correlated only with low silica concentrations. In a study by Wetz and Wheeler (2003) silica uptake by L. minimum was two times lower than that of Chaetoceros socialis. This might indicate a competitive advantage in low silica conditions.

The typical summer coccolithophorids Rhabdosphaera clavigera and Syracosphaera pulchra were related to high temperatures and low nitrate concentrations, as similarly reported by Bernardi Aubry et al. (2006) for the north-western Adriatic coast. Both species are characteristic for subtropical water masses (Malinverno et al., 2009). Haidar and Thierstein (2001) confirmed correlations to temperature and nitrogen for R. clavigera, while $S$. pulchra is known to thrive in oligotrophic stratified conditions (Malinverno et al., 2009). The diatom species Chaetoceros vixvisibilis was found to be directly related to the regime of the Po River flow (Hernández-Becerril et al., 2010). In our study it reached bloom abundances in July 2009 when the Po plume spread over the entire basin. We found it to be most abundant at $10 \mathrm{~m}$ depth, indicating an aggregation due to slow sinking rates of this chain forming diatom (Lunven et al., 2005).

Autumn assemblage of Asterionellopsis glacialis and Calciosolenia murrayi were related to elevated nutrient concentrations. Pannard et al. (2008) found A. glacialis to thrive under higher nutrient levels and in turbid waters, while Andruleit et al. (2003) reported similar characteristic for C. murrayi. This coccolithophorid species was able to find favourable living conditions despite the abundant occurrence of diatoms and low light transmission values. C. socialis was reported as spring diatom in the western part of the northern Adriatic (Bernardi Aubry et al., 2004). We found it as a characteristic autumn species along the eastern area. Booth et al. (2002) found C. socialis to be able to maintain populations at low productivity until nutrients were replenished. We hypothesise that the eastern population might serve as a seeding population for the spring bloom along the western coast of the Adriatic, either by vegetative cells or resting spores. Apart from those typical autumn species, we also recorded Paralia sulcata, Ophiaster hydroideus and Dictyocha fibula as 
important during this season. $P$. sulcata did not typically form large blooms, but was found during the mixed periods by Shon et al.(2008), and we recorded it as one of the characteristic autumn species. It was positively related to nutrient concentrations, similarly reported by Gebühr et al. (2009). O. hydroideus was assumed to have an affinity to habitats with increased nutrient levels (Andruleit, 2007), and we indeed found it to be related with nutrient rich conditions. We found $D$. fibula in very low abundances and it was related to elevated nutrient concentrations, while Bernardi Aubry et al. (2006) reported it to inversely correlate with temperature and directly with salinity. Nevertheless, However D. fibula is well adapted to a wide range of temperatures and especially sensitive to nutrient inputs, it reaches its maximum in areas where river fluxes are most important (Rigual-Hernández et al., 2010).

The winter assemblage was characterised by large diatoms (Thalassiosira rotula and Neocalyptrella robusta) whose abundances were negatively related to temperature. Thalassiosira species are nutrient-sensitive and need high nutrient concentration to sustain growth and compensate for their high settling rate (Lunven et al., 2005). The temperature supporting $N$. robusta growth was reported to range from $12{ }^{\circ} \mathrm{C}$ up to $28^{\circ} \mathrm{C}$ (Baars, 1988). Although its abundances were always very low in our study we found it important in winter. In this study Skeletonema marinoi, was observed sporadically in the late winter period, and was related to nutrient rich waters. This species is a characteristic winter diatom of the north-western Adriatic (Bernardi Aubry et al., 2006; Bernardi Aubry et al., 2004), and we found it thriving in waters under Po River influence (supplementary Fig $3)$.

Bernardi Aubry et al. (2006) found that main phytoplankton seasonal pattern in the northern Adriatic did not change significantly among years. The seasonal absence of many species is explained by periodicity and rarity, and even though we do not record specimens, some might be present. Discrete samples generally cannot be taken with high enough resolution to reflect the ecosystem's true dynamics. Therefore improvements in spatial (both pelagic and benthic), temporal and species resolution are of vital importance for attempting to understand marine ecosystems and predicting their capability to cope with changing conditions. It is well documented that periods of phytoplankton succession are characteristically in the timescale of a month (Cloern and Jassby, 2008). Hence, even though limits of this dataset should be taken into account, the resolution applied here implies that our findings are to be considered as an indication of actual phytoplankton dynamics. A highly variable ecosystem like the northern Adriatic seems to provide enough niches to sustain a high diversity. 


\section{Acknowledgments}

This research was supported by Croatian Ministry of Science, Education and Sports (project numbers: 098-0982705-2731, 098-0982705-2707, 098-0982705-2724), World Bank (Coastal Cities Pollution Control Project) and European Union IPA project-WICOS (Implementation of the Water Quality Monitoring in the Western Istrian Coastal Sea). Data of the Po River discharges were provided by the "Assessorato della Programmazione, Pianificazione e Ambiente" of the Emilia Romagna region (Italy). The authors are grateful to Dr. T. Đakovac, M. Buterer, P. Krelja and the crew of RV 'Vila Velebita' for help during sampling and analyses. Danilo Degobbis, Blaženka Gašparović and Ingrid Ivančić are thanked for their insightful suggestions for improvement of the manuscript. We are also grateful to a dear colleague, Mike Smith, for English corrections. 


\section{References}

Alkawri, A.A.S., Ramaiah, N., 2010. Spatio-temporal variability of dinoflagellate assemblages in different salinity regimes in the west coast of India. Harmful Algae 9, 153-162.

Andruleit, H., 2007. Status of the Java upwelling area (Indian Ocean) during the oligotrophic northern hemisphere winter monsoon season as revealed by coccolithophores. Mar Micropaleontol 64, 36-51.

Andruleit, H., Stäger, S., Rogalla, U., Čepek, P., 2003. Living coccolithophores in the northern Arabian Sea: ecological tolerances and environmental control. Mar Micropaleontol 49, 157-181. Baars, J., 1988. Autecological investigations on marine diatoms 6: Rhizosolenia robusta Norman, Rhizosolenia imbricata Brightwell and Rhizosolenia shrubsolei Cleve. Aquat Ecol 22, 157-162. Bernardi Aubry, F., Acri, F., 2004. Phytoplankton seasonality and exchange at the inlets of the Lagoon of Venice (July 2001-June 2002). J Mar Syst 51, 65-76.

Bernardi Aubry, F., Acri, F., Bastianini, M., Bianchi, F., Cassin, D., Pugnetti, A., Socal, G., 2006. Seasonal and interannual variations of phytoplankton in the Gulf of Venice (Northern Adriatic Sea). Chem Ecol 22, 71-91.

Bernardi Aubry, F., Berton, A., Bastianini, M., Socal, G., Acri, F., 2004. Phytoplankton succession in a coastal area of the NW Adriatic, over a 10-year sampling period (1990-1999). Cont Shelf Res $24,97-115$.

Bernardi Aubry, F., Cossarini, G., Acri, F., Bastianini, M., Bianchi, F., Camatti, E., De Lazzari, A., Pugnetti, A., Solidoro, C., Socal, G., 2012. Plankton communities in the northern Adriatic Sea: Patterns and changes over the last 30 years. Estuarine, Coastal and Shelf Science. doi:10.1016/j.ecss.2012.03.011

Bignami, F., Sciarra, R., Carniel, S., Santoleri, R., 2007. Variability of Adriatic Sea coastal turbid waters from SeaWiFS imagery. J Geophys Res 112, C03S10.

Bode, A., Álvarez-Ossorio, M.T., González, N., Lorenzo, J., Rodríguez, C., Varela, M., Varela, M.M., 2005. Seasonal variability of plankton blooms in the Ria de Ferrol (NW Spain): II. Plankton abundance, composition and biomass. Estuar Coast Shelf Sci 63, 285-300.

Booth, B.C., Larouche, P., Bélanger, S., Klein, B., Amiel, D., Mei, Z.P., 2002. Dynamics of Chaetoceros socialis blooms in the North Water. Deep-Sea Res Pt II 49, 5003-5025.

Braak, C.J.F.t., Šmilauer, P., 2002. CANOCO reference manual and CanoDraw for Windows user's guide: Software for canonical community ordination (version 4.5). Section on permutation methods. Microcomputer Power, Ithaca NY, USA. 
Breton, E., Rousseau, V., Parent, J.-Y., Ozer, J., Lancelot, C., 2006. Hydroclimatic modulation of diatom/Phaeocystis blooms in nutrient-enriched Belgian coastal waters (North Sea). Limnol Oceanogr 51 1401-1409.

Clarke, K.R., Somerfield, P.J., Chapman, M.G., 2006. On resemblance measures for ecological studies, including taxonomic dissimilarities and a zero-adjusted Bray-Curtis coefficient for denuded assemblages. J Exp Mar Biol Ecol 330, 55-80.

Clarke, K.R., Warwick, R.M., 2001. Changes in marine communities: An approach to statistical analysis and interpretation, 2nd edition. Primer-E, Plymouth.

Cloern, J.E., Jassby, A.D., 2008. Complex seasonal patterns of primary producers at the land-sea interface. Ecol Lett 11, 1294-1303.

Cozzi, S., Giani, M., 2011. River water and nutrient discharges in the Northern Adriatic Sea:

Current importance and long term changes. Cont Shelf Res 31, 1881-1893.

Cushman-Roisin, B., Gačić, M., Poulain, P.M., Artegiani, A., 2001. Physical oceanography of the Adriatic Sea: Past, present and future. Springer, New York.

Degobbis, D., Precali, R., Ivančić, I., Smodlaka, N., Fuks, D., Kveder, S., 2000. Long-term changes in the northern Adriatic ecosystem related to anthropogenic eutrophication. Int J Environ Pollut 13, 495-533.

Feldman, G.C., McClain, C.R., 2009. Ocean Color Web, in: Kuring, N., Bailey, S.W. (Eds.), MODIS/AQUA reprocessing 2009.1. NASA Goddard Space Flight Center.

Frka, S., Gašparović, B., Marić, D., Godrijan, J., Djakovac, T., Vojvodić, V., Dautović, J., Kozarac, Z., 2011. Phytoplankton driven distribution of dissolved and particulate lipids in a semi-enclosed temperate sea (Mediterranean): Spring to summer situation. Estuar Coast Shelf Sci 93, 290-304. Gebühr, C., Wiltshire, K., Aberle, N., van Beusekom, J., Gerdts, G., 2009. Influence of nutrients, temperature, light and salinity on the occurrence of Paralia sulcata at Helgoland Roads, North Sea. Aquat Biol 7, 185-197.

Gómez, F., Gorsky, G., 2003. Annual microplankton cycles in Villefranche Bay, Ligurian Sea, NW Mediterranean. J Plankton Res 25, 323-339.

Haidar, A.T., Thierstein, H.R., 2001. Coccolithophore dynamics off Bermuda (N. Atlantic). DeepSea Res Pt II 48, 1925-1956.

Hasle, G.R., 1978. The iverted-microscope method, in: Sournia, A. (Ed.), Phytoplankton Manual. UNESCO, pp. 88-96.

Head, R.N., Crawford, D.W., Egge, J.K., Harris, R.P., Kristiansen, S., Lesley, D.J., Marañón, E., Pond, D., Purdie, D.A., 1998. The hydrography and biology of a bloom of the coccolithophorid Emiliania huxleyi in the northern North Sea. J Sea Res 39, 255-266. 
Hernández-Becerril, D.U., Viličić, D., Bosak, S., Djakovac, T., 2010. Morphology and ecology of the diatom Chaetoceros vixvisibilis (Chaetocerotales, Bacillariophyceae) from the Adriatic Sea. J Plankton Res 32, 1513-1525.

Ivančić, I., Degobbis, D., 1984. An optimal manual procedure for ammonia analysis in natural waters by the indophenol blue method. Water Res 18, 1143-1147.

Ivančić, I., Radić, T., Lyons, D.M., Fuks, D., Precali, R., Kraus, R., 2009. Alkaline phosphatase activity in relation to nutrient status in the northern Adriatic Sea. Mar Ecol Prog Ser 378, 27-35. Ji, R., Edwards, M., Mackas, D.L., Runge, J.A., Thomas, A.C., 2010. Marine plankton phenology and life history in a changing climate: Current research and future directions. J Plankton Res 32, $1355-1368$.

Legendre, L., 1990. The significance of microalgal bloom for fisheries and for the export of particulate organic carbon in oceans. J Plankton Res 12, 681-699.

Lunven, M., Guillaud, J.F., Youénou, A., Crassous, M.P., Berric, R., Le Gall, E., Kérouel, R., Labry, C., Aminot, A., 2005. Nutrient and phytoplankton distribution in the Loire River plume (Bay of Biscay, France) resolved by a new Fine Scale Sampler. Estuar Coast Shelf Sci 65, 94-108. Malinverno, E., Triantaphyllou, M.V., Stavrakakis, S., Ziveri, P., Lykousis, V., 2009. Seasonal and spatial variability of coccolithophore export production at the South-Western margin of Crete (Eastern Mediterranean). Mar Micropaleontol 71, 131-147.

Mangoni, O., Modigh, M., Mozetič, P., Bergamasco, A., Rivaro, P., Saggiomo, V., 2008. Structure and photosynthetic properties of phytoplankton assemblages in a highly dynamic system, the Northern Adriatic Sea. Estuar Coast Shelf Sci 77, 633-644.

Marić, D., Kraus, R., Godrijan, J., Supić, N., Djakovac, T., Precali, R., 2012. Phytoplankton response to climatic and anthropogenic influences in the north-eastern Adriatic during the last four decades. Estuarine, Coastal and Shelf Science. doi:10.1016/j.ecss.2012.02.003

Marić, D., Ljubešić, Z., Godrijan, J., Viličić, D., Ujević, I., Precali, R., 2011. Blooms of the potentially toxic diatom Pseudo-nitzschia calliantha Lundholm, Moestrup \& Hasle in coastal waters of the northern Adriatic Sea (Croatia). Estuar Coast Shelf Sci 92, 323-331.

Martin, A.P., 2003. Phytoplankton patchiness: the role of lateral stirring and mixing. Prog Oceanogr $57,125-174$.

Mauri, E., Poulain, P.-M., 2001. Northern Adriatic Sea surface circulation and temperature/pigment fields in September and October 1997. J Mar Syst 29, 51-67.

Monti, M., Minocci, M., Milani, L., Fonda Umani, S., 2012. Seasonal and interannual dynamics of microzooplankton abundances in the Gulf of Trieste (Northern Adriatic Sea, Italy). Estuarine, Coastal and Shelf Science. doi:10.1016/j.ecss.2012.03.032 
Mozetič, P., Francé, J., Kogovšek, T., Talaber, I., Malej, A., 2012. Plankton trends and community changes in a coastal sea (northern Adriatic): Bottom-up vs. top-down control in relation to environmental drivers. Estuarine, Coastal and Shelf Science. doi:10.1016/j.ecss.2012.02.009 O' Reilly, J.E., Maritorena, S., O' Brien, M.C., Siegel, D.A., Toole, D., Menzies, D., Smith, R.C., Mueller, J.L., Mitchell, B.G., Kahru, M., Chavez, F.P., Strutton, P., Cota, G.F., Hooker, S.B., McClain, C.R., Carder, K.L., Muller-Karger, F., Harding, L., Magnuson, A., Phinney, D., Moore, G.E., Aiken, J., Arrigo, K.R., Letelier, R., Culver, M., 2000. SeaWiFS Postlaunch Calibration and Validation Analyses. Part 3, in: Hooker, S.B., Firestone, E.R. (Eds.), SeaWiFS postlaunch technical report series. National Aeronautics and Space Administration, Washington, D.C., p. 49. Pannard, A., Claquin, P., Klein, C., Le Roy, B., Véron, B., 2008. Short-term variability of the phytoplankton community in coastal ecosystem in response to physical and chemical conditions' changes. Estuar Coast Shelf Sci 80, 212-224.

Parsons, T.R., Maita, Y., Lalli, C.M., 1984. A manual of chemical and biological methods for seawater analysis. Pergamon Press Toronto.

Phlips, E., Badylak, S., Christman, M., Lasi, M., 2010. Climatic Trends and Temporal Patterns of Phytoplankton Composition, Abundance, and Succession in the Indian River Lagoon, Florida, USA. Estuaries Coasts 33, 498-512.

Poulain, P.-M., Raicich, F., 2001. Forcings, in: Cushman-Roisin, B., Gačić, M., Poulain, P.-M., Artegiani, A. (Eds.), Physical oceanography of the Adriatic Sea: Past, present and future. Kluwer Academic Publishers, Dordrecht, pp. 45-65.

Revelante, N., Gilmartin, M., 1976. Temporal succession of phytoplankton in the northern Adriatic. J Sea Res 10, 377-396.

Rigual-Hernández, A.S., Bárcena, M.A., Sierro, F.J., Flores, J.A., Hernández-Almeida, I., SanchezVidal, A., Palanques, A., Heussner, S., 2010. Seasonal to interannual variability and geographic distribution of the silicoflagellate fluxes in the Western Mediterranean. Mar Micropaleontol 77, 4657.

Shon, D.-H., Shin, K.-S., Jang, P.-G., Kim, Y.-O., Chang, M., Kim, W.-S., 2008. Effect of thermal stratification and mixing on phytoplankton community structure in the Western Channel of the Korea Strait. Ocean Polar Res 30, 261-275.

Sieburth, J.M., Smetacek, V., Lenz, J., 1978. Pelagic ecosystem structure: Heterotrophic compartments of the plankton and their relationship to plankton size fractions. Limnol Oceanogr 23, 1256-1263.

Sournia, A., 1973. La production primaire planctonique en Mediterranée. Essai de mise a jour. Bulletin de l'Étude en Commun de la Méditerranée 5, 128.

Tomas, C.R., 1997. Identifying marine phytoplankton. Academic Press, San Diego. 
Totti, C., Civitarese, G., Acri, F., Barletta, D., Candelari, G., Paschini, E., Solazzi, A., 2000.

Seasonal variability of phytoplankton populations in the middle Adriatic sub-basin. J Plankton Res 22, 1735-1756.

Utermöhl, H., 1958. Zur Vervollkommnung der quantitativen Phytoplankton-Methodik. Int Ver Theor Angew Limnol Verh 9, 1-40.

Varela, M., Prego, R., Pazos, Y., 2008. Spatial and temporal variability of phytoplankton biomass, primary production and community structure in the Pontevedra Ria (NW Iberian Peninsula): oceanographic periods and possible response to environmental changes. Mar Biol 154, 483-499. Viličić, D., Djakovac, T., Burić, Z., Bosak, S., 2009. Composition and annual cycle of phytoplankton assemblages in the northeastern Adriatic Sea. Bot Mar 52, 291-305.

Wetz, M.S., Wheeler, P.A., 2003. Production and partitioning of organic matter during simulated phytoplankton blooms. Limnol Oceanogr 48, 1808-1817. 


\section{Figures}

Fig 1. Map of the investigated area.

Fig 2. Temperature, salinity, density anomaly, orthophosphate, dissolved inorganic nitrogen and orthosilicate values for all investigated stations and depths in the period 2008-2009 .

Orthophosphate, total inorganic nitrogen and orthosilicate values were plotted on a log-scale.

Fig 3. Surface and satellite chlorophyll $a$ concentrations at the representative station JPG36. Satellite chlorophyll $a$ concentrations were obtained continuously for days without cloud coverage and closest to the time of water sampling. Po River flow rate during 2008-2009.

Fig 4. A) Microplankon and nanoplankton abundance values of all samples for every month during the research period (2008-2009). B) Contribution (\%) of the phytoplankton groups to the total abundance per station for different months.

Fig 5. Total phytoplankton abundances $\left(\right.$ cell L ${ }^{-1}$ ) across the investigated transect in 2008.

Fig 6. Total phytoplankton abundances $\left(\right.$ cell L ${ }^{-1}$ ) across the investigated transect in 2009.

Fig 7. Chlorophyll $a$ concentration retrieved from satellite data for a date closest to the cruise. The data is shown together with a cluster dendrogram for surface samples at each station on the basis of the phytoplankton species compositions and abundances. A) March 2009. B) July 2009.

Fig 8. Results of canonical correspondence analysis of species and environmental data. In both figures the first (horizontal) and second (vertical) ordination axes are presented. A) Triangles give the position of species selected by SIMPER analysis plotted on the ordination diagram (abbreviations in Table 2). Colours indicate the season, the species are characteristic for. B) Physico-chemical variables are ploted together with the position of stations. Length and direction of environmental parameter arrows indicate their importance in terms of influence on the phytoplankton. (Note the different scale between the two representations). 


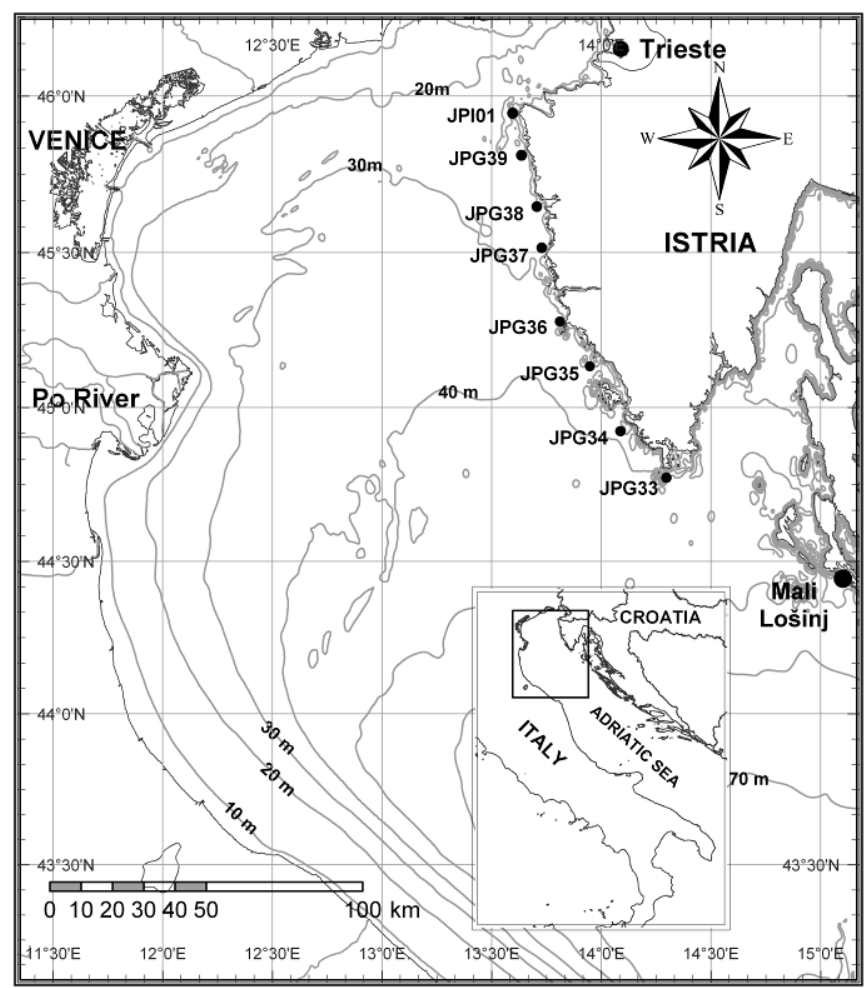

Fig 1. Map of the investigated area.
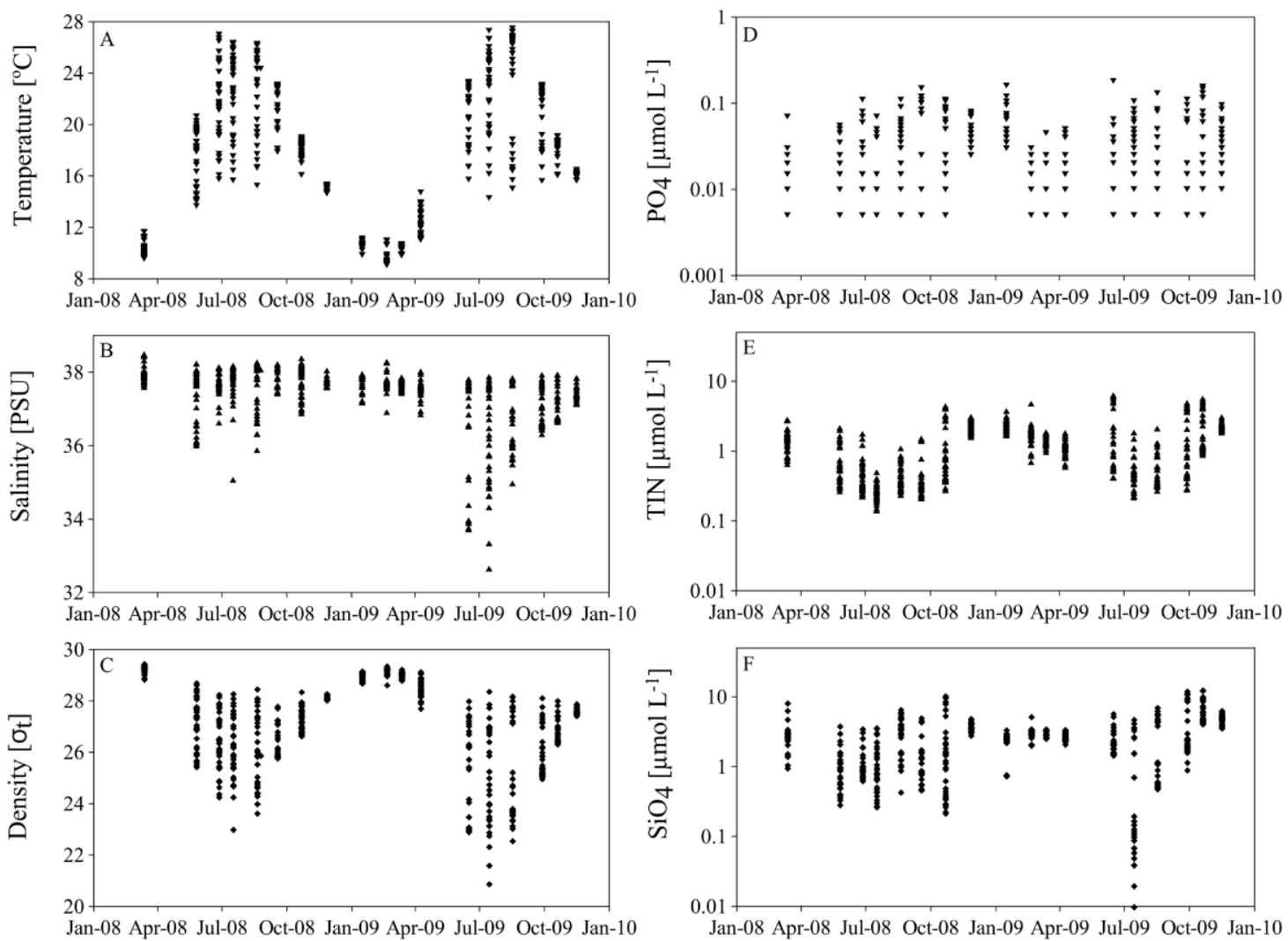

Fig 2. Temperature, salinity, density anomaly, orthophosphate, dissolved inorganic nitrogen and orthosilicate values for all investigated stations and depths in the period 2008-2009 .

Orthophosphate, total inorganic nitrogen and orthosilicate values were plotted on a log-scale. 


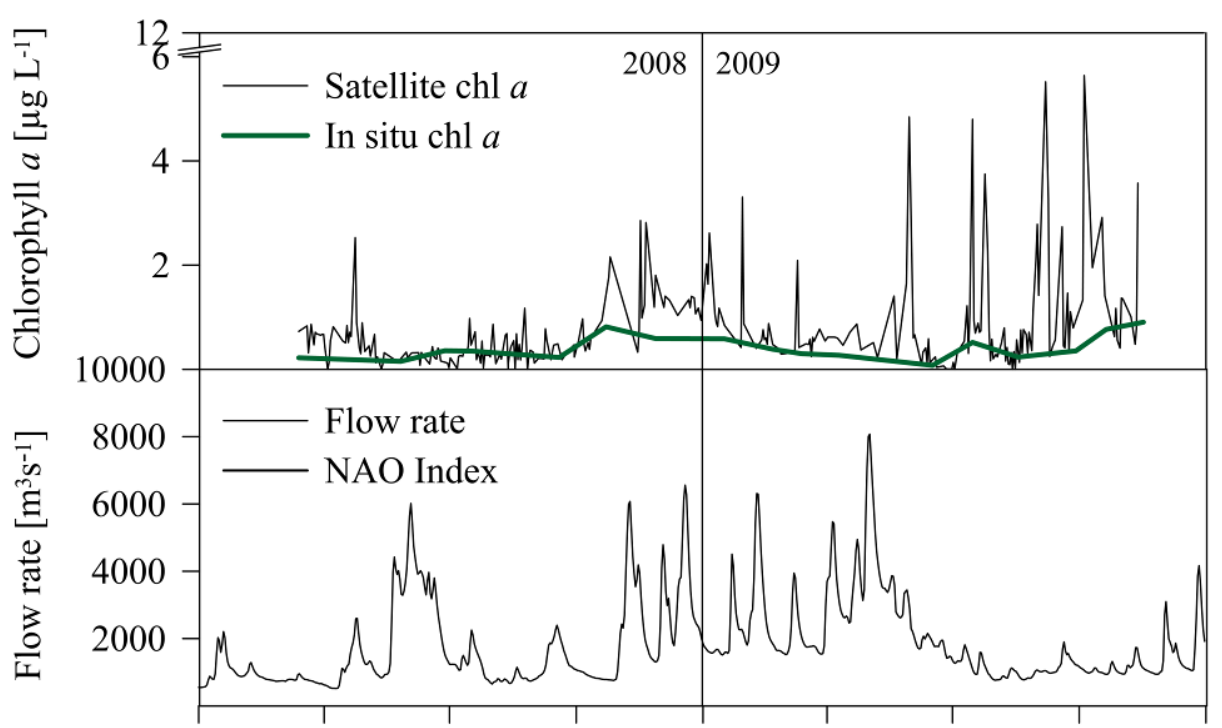

Jan-08 Apr-08 Jul-08 Oct-08 Jan-09 Apr-09 Jul-09 Oct-09 Jan-10

Fig 3. Surface and satellite chlorophyll $a$ concentrations at the representative station JPG36.

Satellite chlorophyll $a$ concentrations were obtained continuously for days without cloud coverage and closest to the time of water sampling. Po River flow rate during 2008-2009.

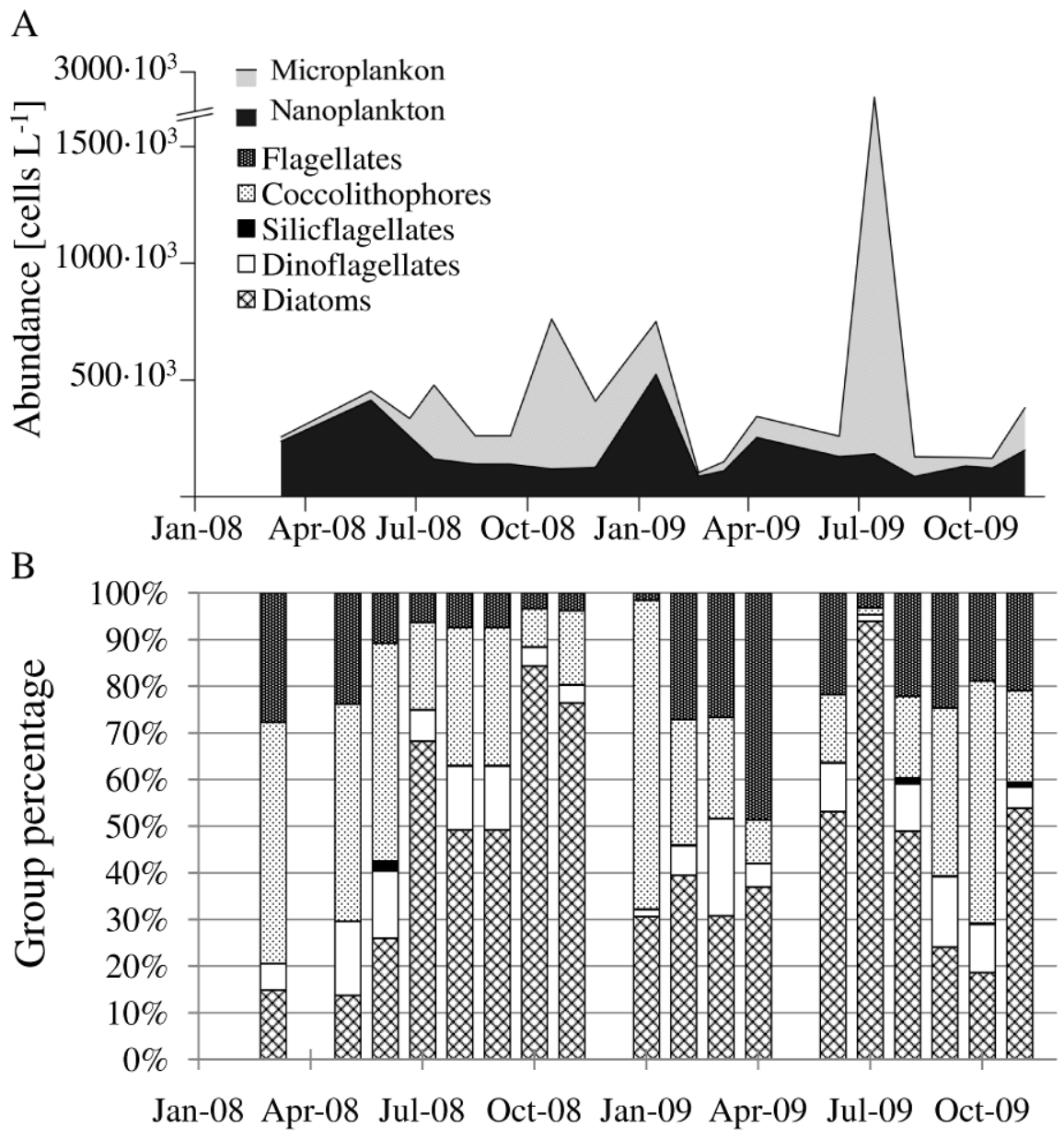

Fig 4. A) Microplankon and nanoplankton abundance values of all samples for every month during the research period (2008-2009). B) Contribution (\%) of the phytoplankton groups to the total abundance per station for different months. 

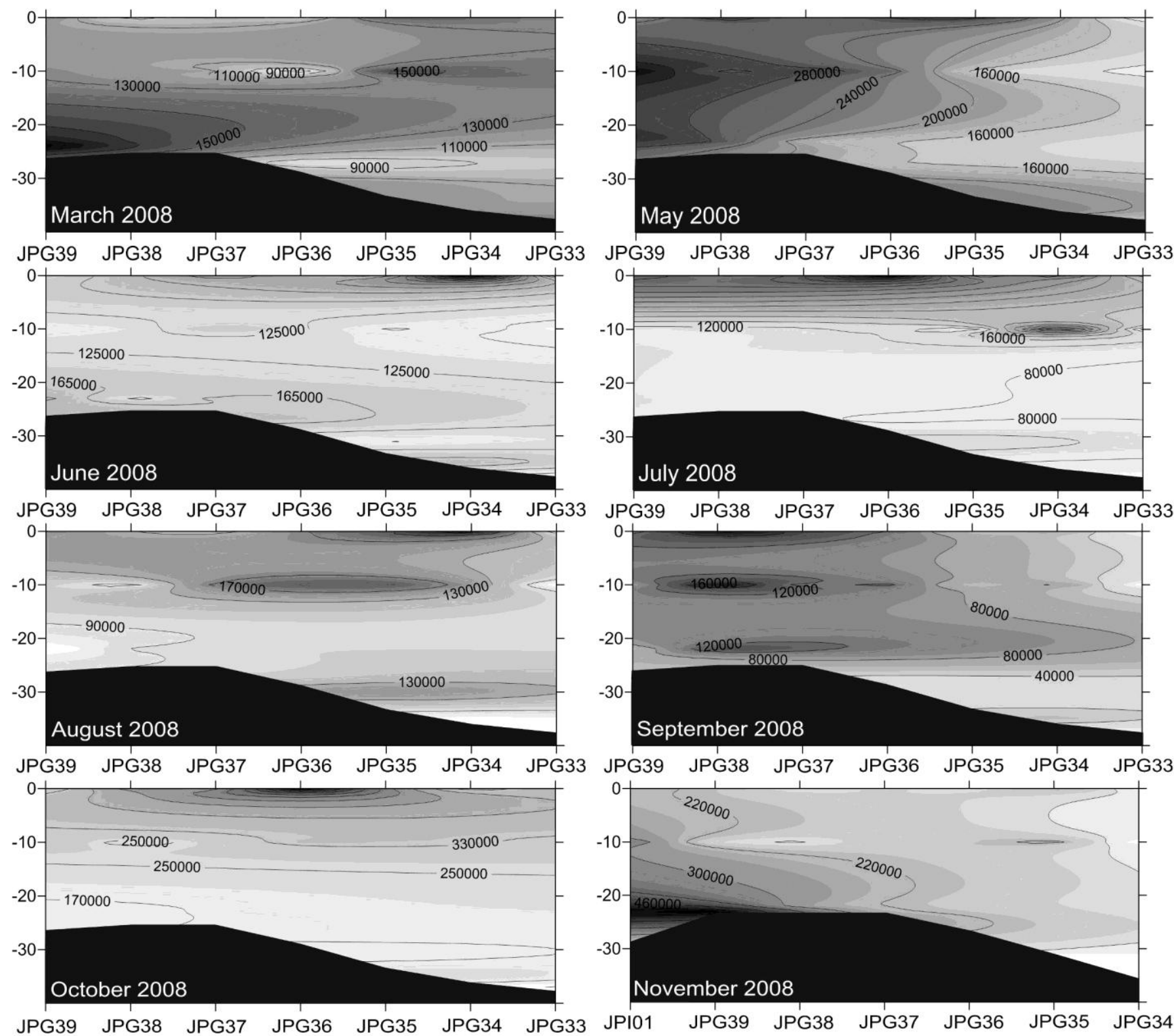

Fig 5. Total phytoplankton abundances (cell $\mathrm{L}^{-1}$ ) across the investigated transect in 2008. 

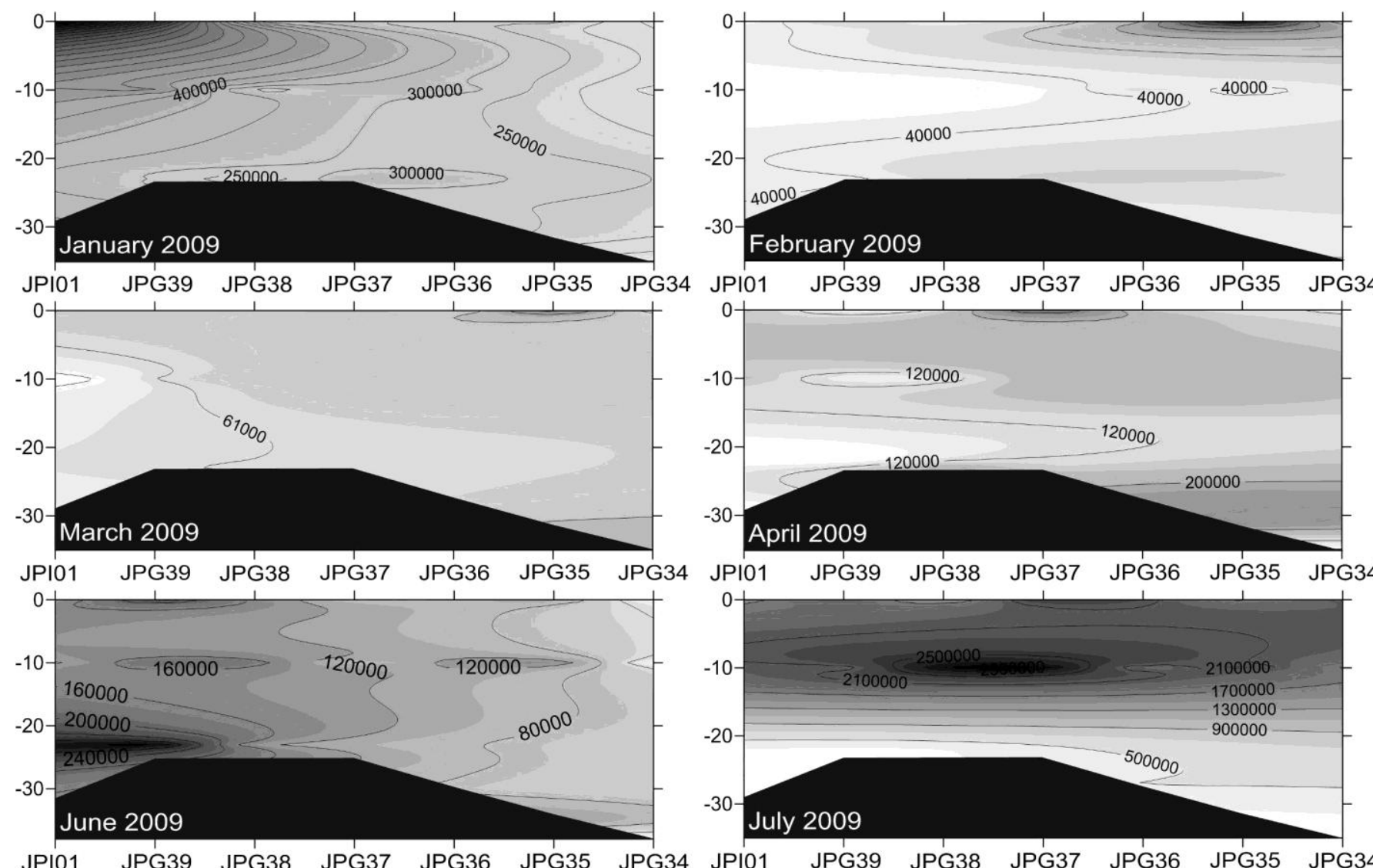

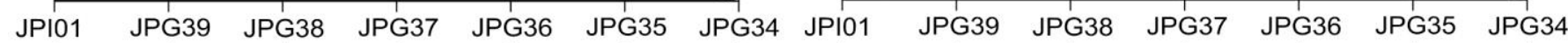
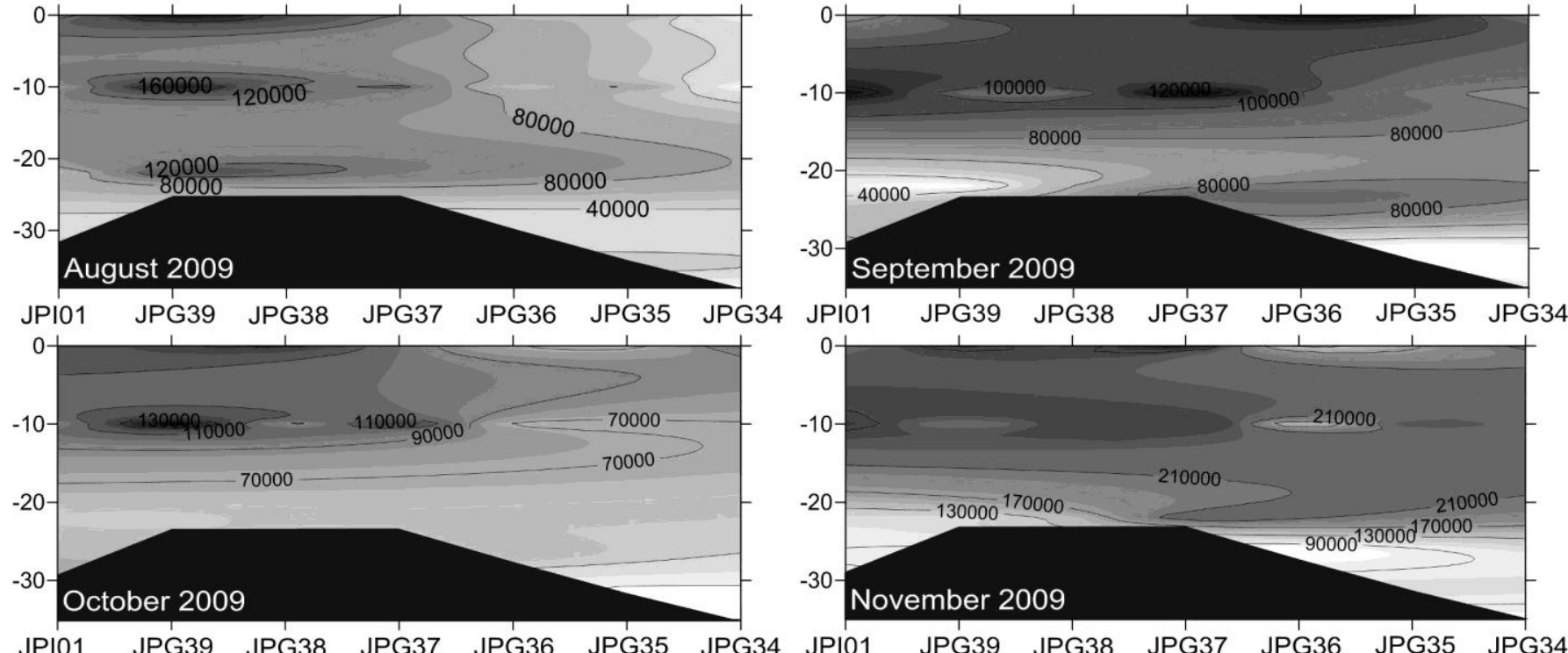

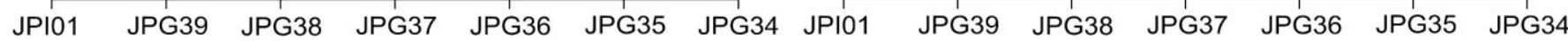

Fig 6. Total phytoplankton abundances (cell $\mathrm{L}^{-1}$ ) across the investigated transect in 2009. 


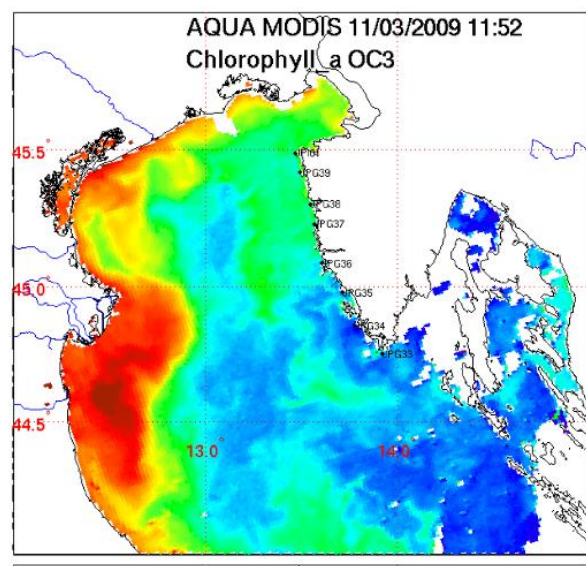

A
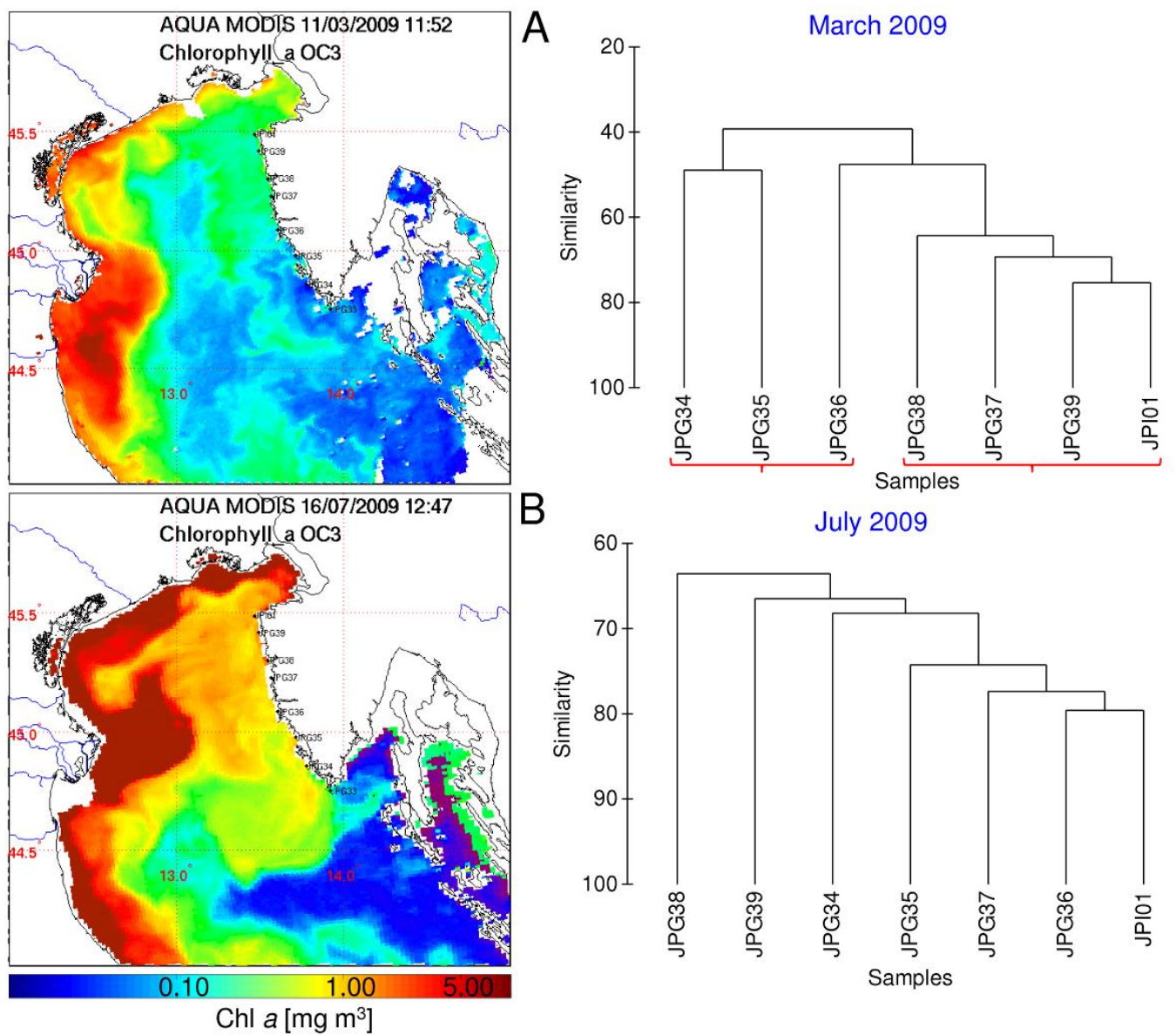

B

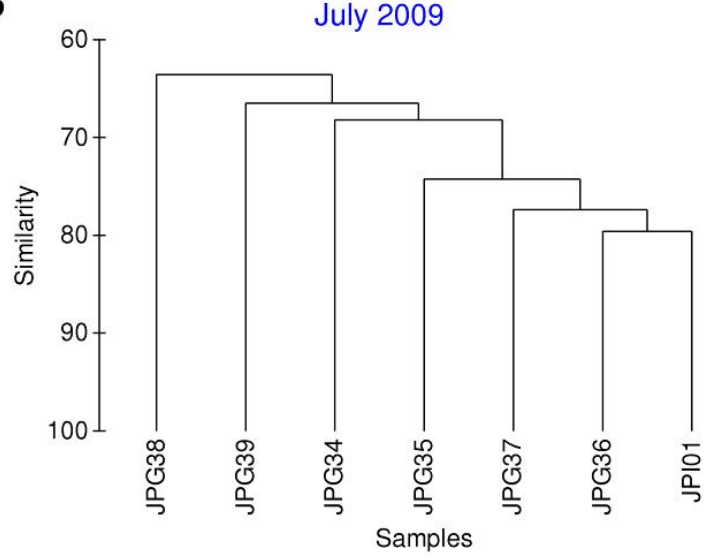

Fig 7. Chlorophyll $a$ concentration retrieved from satellite data for a date closest to the cruise. The data is shown together with a cluster dendrogram for surface samples at each station on the basis of the phytoplankton species compositions and abundances. A) March 2009. B) July 2009. 

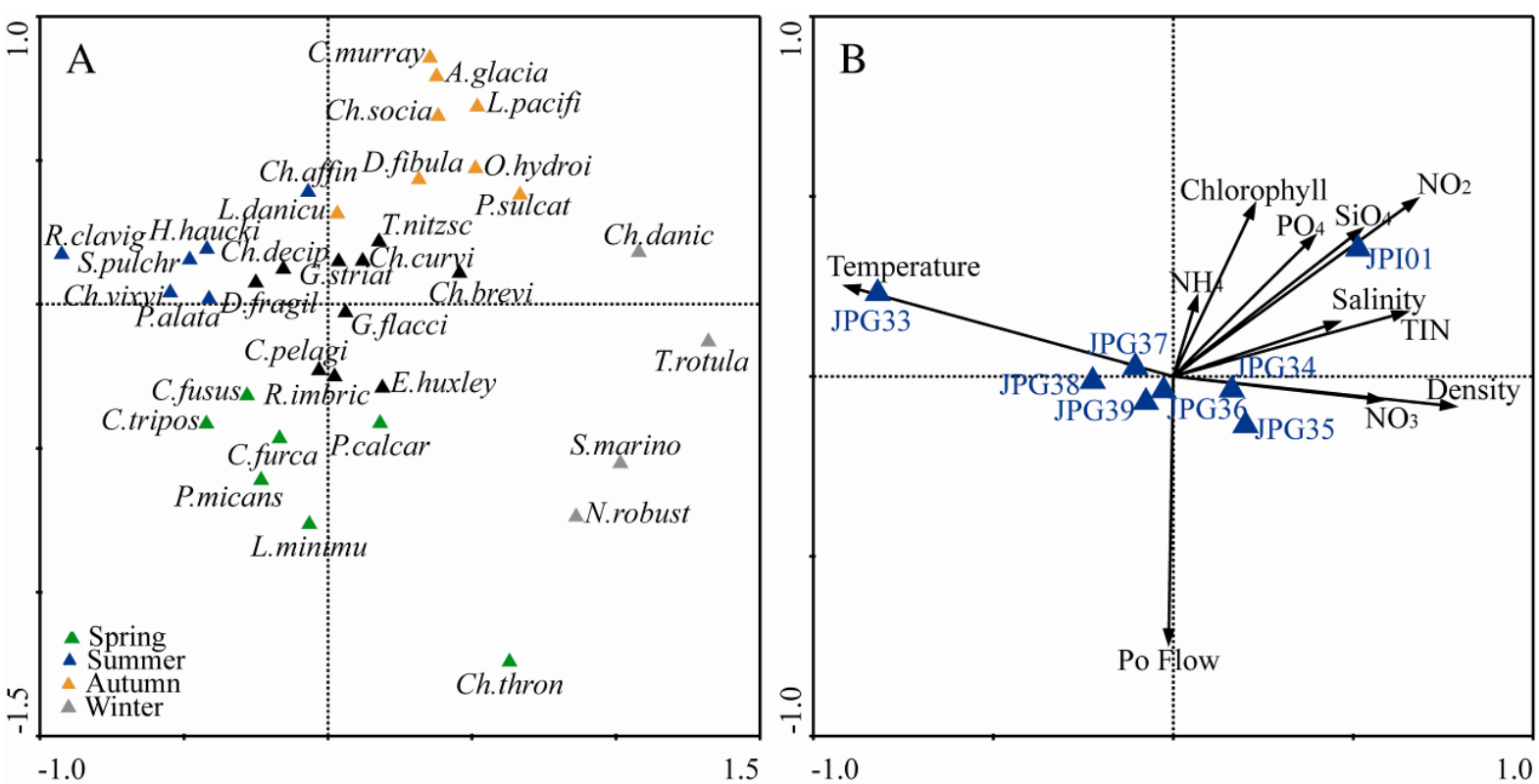

Fig 8. Results of canonical correspondence analysis of species and environmental data. In both figures the first (horizontal) and second (vertical) ordination axes are presented. A) Triangles give the position of species selected by SIMPER analysis plotted on the ordination diagram (abbreviations in Table 2). Colours indicate the season, the species are characteristic for. B) Physico-chemical variables are ploted together with the position of stations. Length and direction of environmental parameter arrows indicate their importance in terms of influence on the phytoplankton. (Note the different scale between the two representations). 
Table1: List of the taxa with a frequency of appearance (in samples) higher than 5\% during the investigated period.

\begin{tabular}{|c|c|c|c|c|}
\hline Taxa & $\begin{array}{l}\text { Frequency of } \\
\text { appearance }\end{array}$ & $\begin{array}{c}\text { Maximal } \\
\text { abundance } \\
\left(\text { cells L L }{ }^{-1}\right)\end{array}$ & $\begin{array}{l}\text { Maximal relative } \\
\text { contribution }\end{array}$ & $\begin{array}{c}\text { Months of maximum } \\
\text { abundance }\end{array}$ \\
\hline \multicolumn{5}{|l|}{ COCCOLITHOPHORES } \\
\hline Calciosolenia brasiliensis (Lohman) Young & $8.89 \%$ & 11360 & $12.60 \%$ & 9 \\
\hline Calciosolenia murrayi Gran & $22.10 \%$ & 26980 & $21.06 \%$ & $9-11$ \\
\hline Emiliania huxleyi (Lohman) Hay et Mohler & $81.40 \%$ & 448720 & $88.20 \%$ & 1 \\
\hline Calciopappus rigidus Heimdal & $7.55 \%$ & 5680 & $6.69 \%$ & 10 \\
\hline Ophiaster hydroideus (Lohmann) Lohmann & $19.95 \%$ & 12780 & $12.99 \%$ & $10-11$ \\
\hline Rhabdosphaera clavigera Murray et Blackman & $30.19 \%$ & 34056 & $31.62 \%$ & $7-8$ \\
\hline Syracosphaera pulchra Lohman & $29.92 \%$ & 22420 & $10.91 \%$ & $7 / 10$ \\
\hline \multicolumn{5}{|l|}{ DIATOMS } \\
\hline Asterionellopsis glacialis (Castracane) Round & $15.09 \%$ & 170240 & $41.10 \%$ & $10-11$ \\
\hline Bacteriastrum delicatulum Cleve & $6.20 \%$ & 64220 & $32.81 \%$ & 6 \\
\hline Bacteriastrum hyalinum Lauder & $9.16 \%$ & 10640 & $5.14 \%$ & Irregular \\
\hline Cerataulina pelagica (Cleve) Hendey & $60.65 \%$ & 147680 & $18.47 \%$ & $5-7$ \\
\hline Chaetoceros affinis Lauder & $29.38 \%$ & 25840 & $6.52 \%$ & 7 \\
\hline Chaetoceros anastomosans Grunow & $7.28 \%$ & 130640 & $33.25 \%$ & $7-8$ \\
\hline Chaetoceros atlanticus Cleve & $14.02 \%$ & 28500 & $10.41 \%$ & 10 \\
\hline Chaetoceros brevis Schütt & $12.13 \%$ & 36920 & $13.75 \%$ & $10-1$ \\
\hline Chaetoceros curvisetus Cleve & $18.60 \%$ & 49020 & $11.59 \%$ & $9-11$ \\
\hline Chaetoceros danicus Cleve & $13.48 \%$ & 14820 & $2.06 \%$ & 1 \\
\hline Chaetoceros decipiens Cleve & $30.19 \%$ & 10260 & $5.68 \%$ & 10,11 \\
\hline Chaetoceros diversus Cleve & $6.74 \%$ & 8360 & $6.02 \%$ & Irregular \\
\hline Chaetoceros lauderi Ralfs & $11.32 \%$ & 11020 & $3.20 \%$ & 7 \\
\hline Chaetoceros lorenzianus Grunow & $6.74 \%$ & 6460 & $5.42 \%$ & 10 \\
\hline Chaetoceros socialis H.S.Lauder & $21.02 \%$ & 545280 & $79.24 \%$ & $9-11$ \\
\hline Chaetoceros spp. & $54.99 \%$ & 81320 & $37.84 \%$ & Irregular \\
\hline $\begin{array}{l}\text { Chaetoceros throndsenii (Marino, Montresor, et } \\
\text { Zingone) Marino, Montresor et Zingone }\end{array}$ & $9.97 \%$ & 28400 & $18.92 \%$ & $3-4$ \\
\hline Chaetoceros tortissimus H.H.Gran & $9.97 \%$ & 28880 & $25.30 \%$ & $7-10$ \\
\hline Chaetoceros vixvisibilis Schiller & $28.84 \%$ & 2893680 & $94.66 \%$ & 7 \\
\hline Cyclotella spp. & $20.22 \%$ & 88040 & $42.92 \%$ & $6 / 11$ \\
\hline $\begin{array}{l}\text { Cylindrotheca closterium/Nitzschia longissima } \\
\text { complex }\end{array}$ & $69.91 \%$ & 337419 & $48.10 \%$ & Irregular \\
\hline Dactyliosolen fragilissimus (Bergon) Hasle & $50.40 \%$ & 56800 & $12.35 \%$ & $7-10$ \\
\hline Diploneis bombus (Ehrenberg) Cleve & $25.61 \%$ & 8520 & $30.56 \%$ & 10 \\
\hline Diploneis spp. & $11.86 \%$ & 5680 & $5.27 \%$ & 10 \\
\hline Ditylum brightwellii (T.West) Grunow & $9.16 \%$ & 5320 & $0.95 \%$ & $1-2$ \\
\hline Eucampia cornuta (Cleve) Grunow & $14.56 \%$ & 102220 & $53.29 \%$ & $9-11$ \\
\hline Guinardia flaccida (Castracane) Peragallo & $56.60 \%$ & 3990 & $3.80 \%$ & Irregular \\
\hline Guinardia striata (Stolterfoth) Hasle & $52.02 \%$ & 24700 & $10.90 \%$ & 11 \\
\hline Hemiaulus hauckii Grunow & $43.94 \%$ & 5700 & $2.31 \%$ & 10 \\
\hline Leptocylindrus danicus Cleve & $42.32 \%$ & 96560 & $52.29 \%$ & $10-11$ \\
\hline Leptocylindrus mediterraneus (H.Peragallo) Hasle & $11.32 \%$ & 21300 & $16.37 \%$ & $9-11$ \\
\hline Leptocylindrus minimus Gran & $11.59 \%$ & 12160 & $6.11 \%$ & 5 \\
\hline Licmophora spp. & $17.25 \%$ & 1520 & $2.05 \%$ & Irregular \\
\hline Lioloma pacificum (Cupp) Hasle & $12.94 \%$ & 5700 & $2.59 \%$ & 11 \\
\hline Navicula spp. & $21.29 \%$ & 31240 & $11.64 \%$ & 11 \\
\hline $\begin{array}{l}\text { Neocalyptrella robusta (G.Norman ex Ralfs) } \\
\text { Hernández-Becerril \& Meave del Castillo }\end{array}$ & $13.75 \%$ & 1900 & $1.27 \%$ & Irregular \\
\hline Paralia sulcata $($ Ehrenberg) Cleve & $18.33 \%$ & 19880 & $12.54 \%$ & $9-1$ \\
\hline Pleurosigma spp. & $37.74 \%$ & 1520 & $2.13 \%$ & Irregular \\
\hline Proboscia alata (Brightwell) Sundström & $16.17 \%$ & 6080 & $1.43 \%$ & 7 \\
\hline Proboscia alata f. gracillima (Cleve) Gran & $50.13 \%$ & 18240 & $8.77 \%$ & $6-7$ \\
\hline Pseudo-nitzschia delicatissima complex & $77.63 \%$ & 365200 & $73.55 \%$ & $8-10$ \\
\hline Pseudo-nitzschia seriata complex & $9.16 \%$ & 39760 & $8.25 \%$ & $11-2$ \\
\hline Pseudosolenia calcar-avis (Schultze) Sundström & $33.69 \%$ & 3420 & $3.63 \%$ & 2 \\
\hline Rhizosolenia imbricata Brightwell & $54.72 \%$ & 9500 & $18.15 \%$ & 2 \\
\hline Rhizosolenia spp. & $5.39 \%$ & 2470 & $3.89 \%$ & Irregular \\
\hline Skeletonema marinoi Sarno \& Zingone & $17.79 \%$ & 594000 & $58.92 \%$ & $1-4$ \\
\hline $\begin{array}{l}\text { Thalassionema nitzschioides (Grunow) } \\
\text { Mereschkowsky }\end{array}$ & $59.84 \%$ & 396000 & $29.40 \%$ & 7 \\
\hline Thalassiosira rotula Meunier & $9.16 \%$ & 20520 & $7.46 \%$ & $11-2$ \\
\hline Thalassiosira spp. & $15.09 \%$ & 48246 & $29.11 \%$ & $9-10$ \\
\hline \multicolumn{5}{|l|}{ DINOFLAGELLATES } \\
\hline Ceratium candelabrum (Ehrenberg) Stein & $7.01 \%$ & 380 & $0.16 \%$ & $5-8$ \\
\hline Ceratium furca (Ehrenberg) Claparéde et Lachmann & $32.88 \%$ & 3420 & $1.19 \%$ & $6-7$ \\
\hline Ceratium fusus (Ehrenberg) Dujardin & $49.87 \%$ & 4180 & $7.82 \%$ & $6-8$ \\
\hline Ceratium trichoceros (Ehrenberg) Kofoid & $17.25 \%$ & 760 & $0.63 \%$ & $8-11$ \\
\hline Ceratium tripos (O.F.Müller) Nitzsch & $17.25 \%$ & 2660 & $1.05 \%$ & 6 \\
\hline Dinophysis caudata Saville-Kent & $7.01 \%$ & 380 & $0.58 \%$ & $7-9$ \\
\hline
\end{tabular}




\begin{tabular}{|c|c|c|c|c|}
\hline Gonyaulax spp. & $7.55 \%$ & 1140 & $1.03 \%$ & $5-7$ \\
\hline Gyrodinium fusiforme Kofoid \& Swezy & $8.89 \%$ & 1520 & $0.95 \%$ & $6-9$ \\
\hline Gyrodinium spp. & $25.61 \%$ & 2840 & $1.84 \%$ & Irregular \\
\hline Prorocentrum compressum (Bailey) Abé ex Dodge & $7.28 \%$ & 950 & $1.74 \%$ & $7-8$ \\
\hline Prorocentrum micans Ehrenberg & $31.27 \%$ & 14200 & $33.99 \%$ & Irregular \\
\hline Prorocentrum minimum (Pavillard) Schiller & $7.55 \%$ & 19880 & $29.06 \%$ & $3-7$ \\
\hline Prorocentrum triestinum J.Schiller & $6.47 \%$ & 14200 & $3.73 \%$ & $6-7$ \\
\hline Pseliodinium vaubanii Soumia & $5.39 \%$ & 1140 & $1.30 \%$ & $6-10$ \\
\hline Scrippsiella spp. & $6.74 \%$ & 1140 & $1.84 \%$ & $7-9$ \\
\hline Torodinium spp. & $12.67 \%$ & 1330 & $1.80 \%$ & 8 \\
\hline \multicolumn{5}{|l|}{ HETEROTHROPHIC DINOFLAGELLATES } \\
\hline Hermesinum adriaticum Zacharias & $6.47 \%$ & 2840 & $1.37 \%$ & $8-11$ \\
\hline Noctiluca scintillans (Macartney) Kofoid et Swezy & $9.97 \%$ & 440 & $0.45 \%$ & $5-7$ \\
\hline Protoperidinium spp. & $10.78 \%$ & 2840 & $0.56 \%$ & $6-7$ \\
\hline Protoperidinium steinii (Jorgensen) Balech & $13.48 \%$ & 2660 & $2.07 \%$ & 6 \\
\hline \multicolumn{5}{|l|}{ SILICOFLAGELLATES } \\
\hline Dictyocha fibula Ehrenberg & $17.79 \%$ & 18288 & $8.32 \%$ & $6-9$ \\
\hline Dictyocha speculum Ehrenberg & $12.94 \%$ & 51207 & $23.29 \%$ & $6-8$ \\
\hline
\end{tabular}


Table 2. List of higher contributing species (> 90\%) within each season determined by similarity percentage analyses (SIMPER), based on log transformed abundance data and Bray-Curtis similarity measure ( $\hat{\mathrm{S}}=$ average similarity within the season).

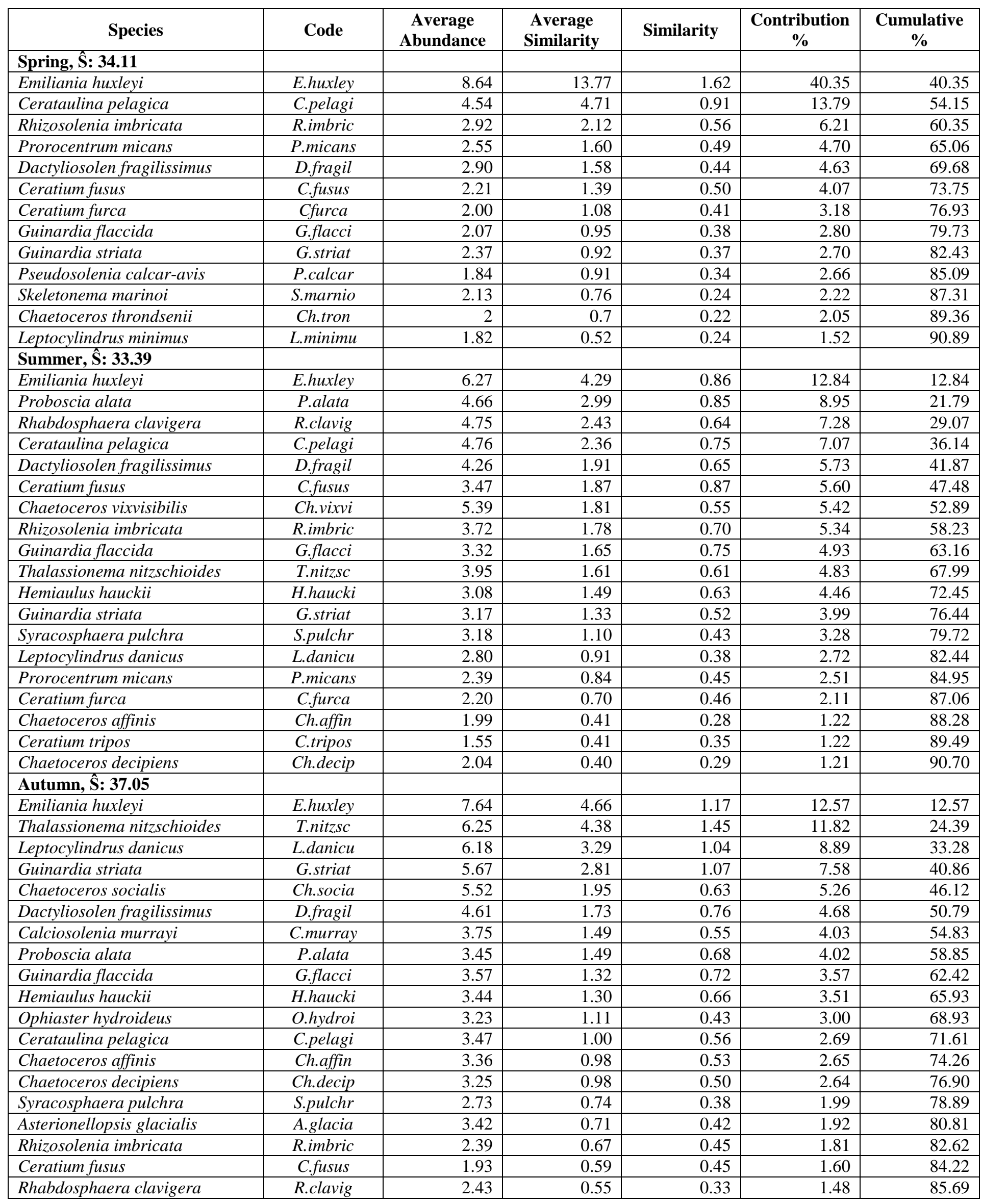




\begin{tabular}{|c|c|c|c|c|c|c|}
\hline Paralia sulcata & P.sulcat & 1.80 & 0.44 & 0.24 & 1.19 & 86.89 \\
\hline Dictyocha fibula & D.fibula & 1.63 & 0.43 & 0.31 & 1.17 & 88.06 \\
\hline Lioloma pacificum & L.pacifi & 2.11 & 0.43 & 0.36 & 1.16 & 89.21 \\
\hline Pseudosolenia calcar-avis & P.calcar & 1.55 & 0.36 & 0.33 & 0.97 & 90.19 \\
\hline Emiliania huxleyi & E.huxley & 10.70 & 13.05 & 3.15 & 31.80 & 31.80 \\
\hline Rhizosolenia imbricata & R.clavig & 4.83 & 4.82 & 1.03 & 11.75 & 43.55 \\
\hline Skeletonema marinoi & S.marino & 5.15 & 2.30 & 0.63 & 5.60 & 64.83 \\
\hline Thalassiosira rotula & T.rotula & 4.49 & 2.24 & 0.66 & 5.46 & 70.29 \\
\hline Cerataulina pelagica & C.pelagi & 3.90 & 2.17 & 0.75 & 5.28 & 75.57 \\
\hline Chaetoceros danicus & Ch.danic & 3.78 & 1.68 & 0.63 & 4.09 & 79.66 \\
\hline Neocalyptrella robusta & N.robust & 2.17 & 1.07 & 0.47 & 2.62 & 82.28 \\
\hline Pseudosolenia calcar-avis & P.calcar & 1.95 & 0.96 & 0.35 & 2.35 & 84.63 \\
\hline Chaetoceros curvisetus & Ch.curvi & 1.94 & 0.44 & 0.28 & 1.07 & 90.87 \\
\hline
\end{tabular}


Table 3. Spearman correlation matrix of physico-chemical variables and species (bold=significant correlations with $\mathrm{P}<0.01)$.

\begin{tabular}{|c|c|c|c|c|c|c|c|c|c|c|c|}
\hline Species & Temp & Sal & $\mathrm{PO}_{4}$ & $\mathrm{NO}_{3}$ & $\mathrm{NO}_{2}$ & $\mathrm{NH}_{4}$ & $\mathrm{SiO}_{4}$ & TIN & Chll a & Flow & Density \\
\hline \multicolumn{12}{|l|}{ Spring } \\
\hline Ceratium fusus & 0.30 & -0.35 & -0.07 & -0.21 & -0.27 & 0.08 & -0.20 & -0.19 & 0.05 & -0.02 & -0.36 \\
\hline Ceratium tripos & 0.22 & -0.19 & -0.05 & -0.15 & -0.23 & 0.17 & -0.10 & -0.11 & 0.02 & 0.09 & -0.23 \\
\hline Ceratium furca & 0.14 & -0.27 & -0.08 & -0.06 & -0.16 & 0.09 & -0.14 & -0.04 & -0.05 & 0.08 & -0.19 \\
\hline Chaetoceros throndsenii & -0.20 & -0.08 & -0.05 & 0.18 & 0.09 & -0.04 & 0.07 & 0.12 & -0.07 & 0.26 & 0.16 \\
\hline Leptocylindrus minimus & 0.01 & -0.03 & -0.10 & -0.10 & -0.10 & -0.05 & -0.17 & -0.11 & -0.13 & 0.13 & -0.02 \\
\hline Prorocentrum micans & 0.18 & -0.29 & -0.12 & -0.07 & -0.18 & 0.05 & -0.10 & -0.08 & -0.12 & 0.17 & -0.22 \\
\hline Pseudosolenia calcar-avis & -0.13 & -0.02 & -0.06 & 0.09 & 0.06 & -0.04 & 0.05 & 0.07 & 0.02 & 0.09 & 0.11 \\
\hline \multicolumn{12}{|l|}{ Summer } \\
\hline Chaetoceros affinis & 0.14 & -0.05 & 0.12 & -0.08 & 0.04 & 0.09 & -0.01 & -0.04 & 0.31 & -0.31 & -0.13 \\
\hline Chaetoceros vixvisibilis & 0.37 & -0.11 & -0.01 & -0.37 & -0.36 & 0.00 & -0.41 & -0.35 & 0.06 & -0.07 & -0.34 \\
\hline Hemiaulus hauckii & 0.40 & -0.02 & 0.00 & -0.43 & -0.34 & 0.10 & -0.20 & -0.38 & 0.16 & -0.15 & -0.36 \\
\hline Proboscia alata & 0.47 & -0.05 & -0.08 & -0.45 & -0.42 & 0.07 & -0.32 & -0.41 & -0.03 & 0.04 & -0.43 \\
\hline Rhabdosphaera clavigera & 0.61 & -0.33 & -0.18 & -0.45 & -0.54 & -0.12 & -0.43 & -0.50 & -0.11 & -0.20 & -0.60 \\
\hline Syracosphaera pulchra & 0.35 & -0.31 & 0.00 & -0.29 & -0.25 & -0.01 & -0.26 & -0.28 & 0.18 & -0.24 & -0.38 \\
\hline \multicolumn{12}{|l|}{ Autumn } \\
\hline Asterionellopsis glacialis & -0.03 & 0.06 & 0.23 & 0.06 & 0.27 & 0.23 & 0.13 & 0.16 & 0.35 & -0.34 & 0.02 \\
\hline Calciosolenia murrayi & 0.04 & -0.04 & 0.29 & 0.15 & 0.36 & 0.35 & 0.40 & 0.29 & 0.46 & -0.33 & -0.06 \\
\hline Chaetoceros socialis & -0.02 & 0.15 & 0.24 & 0.11 & 0.31 & 0.20 & 0.16 & 0.19 & 0.40 & -0.15 & 0.04 \\
\hline Dictyocha fibula & -0.03 & -0.09 & 0.20 & 0.09 & 0.23 & 0.23 & 0.31 & 0.17 & 0.32 & -0.21 & -0.02 \\
\hline Leptocylindrus danicus & 0.09 & 0.07 & 0.30 & -0.06 & 0.11 & 0.31 & 0.12 & 0.06 & 0.44 & -0.15 & -0.08 \\
\hline Lioloma pacificum & -0.06 & -0.07 & 0.25 & 0.16 & 0.30 & 0.27 & 0.20 & 0.25 & 0.39 & -0.24 & 0.02 \\
\hline Ophiaster hydroideus & -0.06 & -0.17 & 0.17 & 0.24 & 0.42 & 0.17 & 0.32 & 0.30 & 0.37 & -0.29 & 0.00 \\
\hline Paralia sulcata & -0.13 & 0.28 & 0.45 & 0.11 & 0.27 & 0.30 & 0.33 & 0.26 & 0.32 & -0.07 & 0.16 \\
\hline \multicolumn{12}{|l|}{ Winter } \\
\hline Chaetoceros danicus & -0.27 & -0.01 & 0.29 & 0.34 & 0.48 & 0.11 & 0.23 & 0.40 & 0.35 & -0.12 & 0.23 \\
\hline Neocalyptrella robusta & -0.34 & 0.12 & -0.03 & 0.24 & 0.20 & -0.18 & 0.04 & 0.18 & 0.02 & 0.16 & 0.32 \\
\hline Skeletonema marinoi & -0.35 & 0.12 & 0.16 & 0.30 & 0.33 & -0.10 & 0.05 & 0.29 & 0.07 & 0.13 & 0.34 \\
\hline Thalassiosira rotula & -0.29 & 0.12 & 0.23 & 0.25 & 0.36 & -0.07 & 0.05 & 0.28 & 0.20 & -0.01 & 0.29 \\
\hline All seasons & & & & & & & & & & & \\
\hline
\end{tabular}

